\title{
PKC $\theta$ is required for alloreactivity and GVHD but not for immune responses toward leukemia and infection in mice
}

\author{
Javier O. Valenzuela, ${ }^{1}$ Cristina Iclozan, ${ }^{1}$ Mohammad S. Hossain, ${ }^{2}$ Martin Prlic, ${ }^{3}$ Emily Hopewell, ${ }^{1}$
} Crystina C. Bronk, ${ }^{1}$ Junmei Wang, ${ }^{1}$ Esteban Celis, ${ }^{1,4}$ Robert W. Engelman, ${ }^{1,4}$ Bruce R. Blazar, ${ }^{5}$ Michael J. Bevan, ${ }^{3}$ Edmund K. Waller, ${ }^{2}$ Xue-Zhong Yu, ${ }^{1,4}$ and Amer A. Beg,

\begin{abstract}
${ }^{1} \mathrm{H}$. Lee Moffitt Cancer Center and Research Institute, Tampa, Florida, USA. ${ }^{2}$ Hematology and Oncology Department, Division of Stem Cell and Bone Marrow Transplantation, Emory University School of Medicine, Atlanta, Georgia, USA. ${ }^{3}$ Department of Immunology and Howard Hughes Medical Institute, University of Washington, Seattle, Washington, USA. ${ }^{4}$ Department of Oncologic Sciences, College of Medicine, University of South Florida, Tampa, Florida, USA.

${ }^{5}$ Pediatric Blood and Marrow Transplantation Program, University of Minnesota, Minneapolis, Minnesota, USA.
\end{abstract}

\begin{abstract}
When used as therapy for hematopoietic malignancies, allogeneic BM transplantation (BMT) relies on the graftversus-leukemia (GVL) effect to eradicate residual tumor cells through immunologic mechanisms. However, graft-versus-host disease (GVHD), which is initiated by alloreactive donor $\mathrm{T}$ cells that recognize mismatched major and/or minor histocompatibility antigens and cause severe damage to hematopoietic and epithelial tissues, is a potentially lethal complication of allogeneic BMT. To enhance the therapeutic potential of BMT, we sought to find therapeutic targets that could inhibit GVHD while preserving GVL and immune responses to infectious agents. We show here that $\mathrm{T}$ cell responses triggered in mice by either Listeria monocytogenes or administration of antigen and adjuvant were relatively well preserved in the absence of PKC isoform $\theta$ (PKC $\theta$ ), a key regulator of TCR signaling. In contrast, PKC $\theta$ was required for alloreactivity and GVHD induction. Furthermore, absence of PKC $\theta$ raised the threshold for $\mathrm{T}$ cell activation, which selectively affected alloresponses. Most importantly, $\mathrm{PKC} \theta$-deficient $\mathrm{T}$ cells retained the ability to respond to virus infection and to induce GVL effect after BMT. These findings suggest $P K C \theta$ is a potentially unique therapeutic target required for GVHD induction but not for GVL or protective responses to infectious agents.
\end{abstract}

\section{Introduction}

The primary signal for $\mathrm{T}$ cell activation is delivered by engagement of the TCR with MHC/peptide complexes on APCs. In addition, a second signal is provided by costimulatory molecules belonging to B7 and TNF receptor (TNFR) superfamilies $(1,2)$, while inflammatory cytokines provide the third signal (3). TCR signaling requires key protein tyrosine kinases, including Lck and ZAP70, which mediate activation of multiple signaling pathways (4). PKC isoform $\theta$ (PKC $\theta$ ) is thought to be a key modulator of TCR signaling $(5,6)$. PKC $\theta$ is positioned in the immunological synapse during $\mathrm{T}$ cell activation and, together with the CARMA and $\mathrm{Bcl}-10$ adaptors, mediates TCR activation by inducing NF-KB, NF-AT, and AP-1 transcription factors $(5,6)$. However, the specific roles of these transcription factors in mediating different PKC $\theta$-induced responses are unclear. Studies of $P K C \theta^{-/-}$mice have shown normal $\mathrm{T}$ cell development but greatly impaired in vitro proliferative responses (7-9).

In vivo studies have indicated important roles for PKC $\theta$ in $\mathrm{T}$ cell survival and in promoting activation versus tolerance (10, 11). Recent studies have also shown that PKC $\theta$ is important in the induction of experimentally induced autoimmune diseases in the mouse, including encephalomyelitis, arthritis, and myocarditis (12-14). Additionally, PKCO is involved in generation of

Authorship note: Javier O. Valenzuela and Cristina Iclozan contributed equally to this work. Xue-Zhong Yu and Amer A. Beg contributed equally to this work.

Conflict of interest: The authors have declared that no conflict of interest exists. Citation for this article: J. Clin. Invest. 119:3774-3786 (2009). doi:10.1172/JCI39692.
Th2 responses (15). However, PKC $\theta$ is not required for induction of Th1 responses against Leishmania major, and most important, $\mathrm{PKC}^{-/}$- mice mount normal CD8 $\mathrm{T}$ cell proliferative and cytotoxic responses against several different viruses $(15,16)$. The molecular basis for why $\mathrm{PKC}^{---} \mathrm{T}$ cell proliferation is impaired in vitro yet normal under certain conditions in vivo is not completely clear.

Although PKC $\theta$ has been shown to be important for induction of experimental autoimmune diseases in the mouse, the human counterparts of these ailments likely follow a different etiology. Thus, specific situations in which PKC $\theta$ inhibition may be therapeutically efficacious have yet to be defined. Graft-versus-host disease (GVHD) is a potentially lethal consequence of allogeneic BM transplantation (BMT) for which mouse models that recapitulate human GVHD have been established (17). GVHD is initiated by donor $\mathrm{T}$ cells that specifically recognize mismatched major (MHC) and/or minor (MiHA) histocompatibility antigens of the recipient (17-19). These alloreactive $\mathrm{T}$ cells undergo robust expansion and functional differentiation within recipients and cause severe damage to the gut, liver, and skin (17-19). Consequently, therapeutic immunosuppressive regimens that prevent $\mathrm{T}$ cell activation can limit the deleterious effects of GVHD as well as organ transplant rejection (17-19). However, because commonly used agents such as cyclosporine and FK506 are broadly immunosuppressive, they also render recipients susceptible to life-threatening infections $(20,21)$. The use of allogeneic BMT in patients with nonmalignant disorders, such as sickle-cell anemia, is limited by GVHD toxicity as well as increased risk of infection following immunosuppression (17). When used as immunotherapy for hematopoietic malignances 
(e.g., leukemia), the therapeutic potential of allogeneic BMT relies on the graft-versus-leukemia (GVL) effect to eradicate residual tumor cells through immunologic mechanisms (22). A key goal of research in this area is to identify targets and modalities that can be used to prevent GVHD while preserving GVL and responses against infectious agents. The studies described here help define key aspects of PKC $\theta$ function and validate PKC $\theta$ as a potential therapeutic target for inhibition of GVHD while sparing donor $\mathrm{T}$ cell-mediated antileukemia and antiinfection responses.

\section{Results}

Distinct roles of $P K C \theta$ in regulating T cell proliferation in vitro and in vivo. To utilize a system whereby TCR stimulation is provided by the same agonist in vitro and in vivo, we crossed $P \mathrm{KCO}^{-/-}$mice (7) to $\mathrm{OVA}_{257-264-s p e c i f i c ~ O T-1}$ TCR Tg mice. CD8 T cells from WT and $\mathrm{PKC}^{-/} \mathrm{OT}-1$ mice were stimulated with microspheres coated with $\mathrm{OVA}_{257-264}$-pulsed dimeric $\mathrm{H}-2 \mathrm{~K}^{\mathrm{b}}: \mathrm{Ig}$ plus the CD28 ligand B7.1:Fc. WT cells proliferated vigorously to TCR plus CD28 stimulation. In contrast, $P \mathrm{KC}^{-/-}$cells proliferated weakly during the first 48 hours of culture and did not proliferate beyond that point (Figure 1A). Impaired proliferation of $\mathrm{PKC}^{-/-}$cells was evident over a wide range of peptide concentrations (Figure 1B). These results demonstrate the crucial role of $P \mathrm{KC}^{-/-}$in the proliferation of CD8 T cells responding to antigen in agreement with previous studies using agonistic antibodies to CD3 and CD28 (7). Furthermore, increased cell death in $\mathrm{PKCO}^{-/-}$cells likely contributes to their low levels of proliferation (Supplemental Figure 1; supplemental material available online with this article; doi:10.1172/JCI39692DS1).

To determine whether the requirement for PKC $\theta$ in $\mathrm{T}$ cell proliferation observed in vitro was also evident in vivo, CFSE-labeled WT versus $P \mathrm{KC}^{-/-}$OT-1 CD8 T cells were adoptively transferred by i.v. injection into C57BL/6 CD45.1 congenic recipients, and their levels of CFSE dilution (Figure 1C) and clonal expansion (Figure 1D) were determined after 3 days. s.c. immunizations with LPS (used as microbial adjuvant) alone did not induce $\mathrm{T}$ cell proliferation or clonal expansion in draining lymph nodes when compared with mock injections of PBS (data not shown). Immunization with OVA alone induced proliferation in a small subset of WT and $\mathrm{PKC}^{-/-}$T cells (Figure 1C), but this was not accompanied by clonal expansion (Figure 1D). In contrast, LPS plus OVA immunizations induced a strong proliferation response in both WT and $P \mathrm{KC}^{-/-} \mathrm{T}$ cells, and the total numbers of $P K C \theta^{-/-}$cells were only 2 - to 2.5 -fold lower than WT cells. Thus, the in vitro requirement for PKCO in T cell proliferation is not observed in vivo, although it is still important for optimal clonal expansion. To determine whether $\mathrm{PKCO}^{-/-}$ CD8 T cells are also able to kill target cells, CFSE-labeled and OVApulsed syngeneic splenocytes from CD45.2 B6 mice were injected as target cells on day 3 after immunization and their elimination from the host followed 10-12 hours later. As shown in Figure 1E, $\mathrm{PKC}^{-/-} \mathrm{CD} 8 \mathrm{~T}$ cells efficiently cleared injected target cells, indicating apparently normal development of cytolytic effector function in vivo. Thus, $\mathrm{PKC} \theta$ is not essential for antigen-induced CD8 T cell proliferation or differentiation into effector cells.

In vivo activation of endogenous $\mathrm{PKC} \mathrm{H}^{-/-} \mathrm{CD} 8 \mathrm{~T}$ cells by Listeria monocytogenes. We next determined the immune response of endogenous $\mathrm{PKC}^{-/}{ }^{-} \mathrm{CD} 8 \mathrm{~T}$ cells to the bacterial agent $L$. monocytogenes. Importantly, eradication of this agent is known to be dependent on CD8 T cells (23). WT and $P K C \theta^{-/-}$mice were immunized i.v. with a recombinant Listeria strain expressing OVA (LM-OVA), and the levels of OVA-specific T cells and IFN- $\gamma$ and IL-2 production were measured by $\mathrm{K}^{\mathrm{b}} / \mathrm{OVA}$ tetramer and intracellular cytokine staining (Figure 1, F and G). Clonal expansion of endogenous OVA-specific $\mathrm{PKC}^{-/-} \mathrm{CD} 8 \mathrm{~T}$ cells was only 2.1 -fold lower than that of WT cells in response to LM-OVA infection. In addition, IFN- $\gamma$-producing cells were only $52 \%$ lower in $\mathrm{PKCO}^{-/-}$mice than WT cells, although they were severely affected in their ability to produce IL-2. This apparent lack of IL-2 production, however, did not prevent the clonal expansion of tetramer ${ }^{+} P K C \theta^{-/-} \mathrm{CD} 8 \mathrm{~T}$ cells (Figure $1 \mathrm{~F}$ ). Most importantly, no detectable Listeria was found in $\mathrm{PKC}^{-/-}$mice or WT mice 7 days after infection (data not shown). Thus, PKC $\theta$ is not essential for mounting a $\mathrm{T}$ cell response against Listeria or for efficient clearance of this bacterial agent. A recent study showed impaired responsiveness in $\mathrm{PKCO}^{-/-}$mice after Listeria infection (24). Although the reason for differences from our study are not clear, this study used a 25-fold higher LM-OVA amount, indicating potential PKCO dependence in response to very-high-level infectious agent challenge.

Crucial role of $N F-\kappa B$ in mediating PKCO-dependent and-independent responses in CD8 T cells. DCs play a crucial role in naive $T$ cell activation in vivo. To better understand mechanisms responsible for $\mathrm{PKC}^{-/-} \mathrm{T}$ cell proliferation in vivo, we used DCs derived from mouse BM (BMDCs). In contrast to microspheres, $P K C \theta^{-/-} \mathrm{T}$ cell proliferation was only slightly reduced compared with WT T cells in the presence of BMDCs (Figure 2A). Thus, CD8 T cell activation can take place in the absence of $\mathrm{PKC} \theta$, provided that compensatory signals (e.g., costimulatory molecules) on DCs are available. Members of the B7 and TNF families of costimulatory molecules are known to activate NF-KB $(1,2)$, and therefore, $\mathrm{PKC}^{-/-} \mathrm{CD} 8$ $\mathrm{T}$ cell proliferation may be rescued through NF- $\kappa \mathrm{B}$ activation by these molecules expressed on DCs. We first examined NF- $\kappa B$ activation when $P \mathrm{KC}^{-/-}$OT-1 CD8 T cells were stimulated with OVA peptide-pulsed microspheres. NF-KB activation in $\mathrm{PKC}^{-/-}$cells stimulated with OVA alone (i.e., without B7.1) was greatly reduced compared with WT T cells after 18 hours (Figure $2 \mathrm{~B}$ ). The presence of $\mathrm{B} 7$ costimulation increased the level of NF- $\mathrm{\kappa B}$ activation after 18 hours in $\mathrm{PKC}^{-/-}$cells, but it remained lower than in WT cells (Figure 2B). We next determined NF-KB activation when WT and $\mathrm{PKC}^{-/-}$OT-1 CD8 T cells were stimulated with OVA peptide-pulsed BMDCs (Figure 2C). In contrast to microspheres, BMDCs induced roughly equivalent levels of nuclear NF- $\kappa \mathrm{B}$ in WT and $\mathrm{PKC}^{-/-}$cells after 18 hours of stimulation (Figure $2 \mathrm{C}$ ). These results suggest that the presence of additional NF- $\kappa B$-activating molecules on DCs, such as costimulatory molecules, can allow activation of NF- $\mathrm{\kappa B}$ in the absence of PKC $\theta$.

We then determined whether NF-кB activation merely correlated with increased proliferation of $\mathrm{PKC}^{-/-}$cells by DCs or whether it was indeed required for DC-induced $\mathrm{T}$ cell proliferation. For these studies, we used T cells deficient in NF-кB subunits p50 and cRel, in which overall NF- $\kappa$ B activity in CD4 (25) and CD8 T cells (data not shown) is virtually undetectable after activation. CD8 T cells from WT, $\mathrm{PKC} \mathrm{O}^{-/-}$, and $\mathrm{p} 5 \mathrm{O}^{-{ }_{-}} \mathrm{cRel}^{-{ }^{-}}$mice were stimulated with anti-CD3 plus anti-CD28 antibodies in the presence or absence of BMDCs, and the levels of ${ }^{3} \mathrm{H}$-thymidine incorporation were measured after 72 hours (Figure 2D). As expected, proliferation of $\mathrm{PKCO}^{-/-}$and $\mathrm{p50}^{-/-} \mathrm{cRel} \mathrm{l}^{--}$cells was greatly reduced compared with that of WT cells in the absence of BMDCs. In the presence of BMDCs, $P \mathrm{KC}^{-/-}$cells were able to recover and proliferate. In

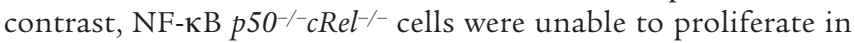
the presence of BMDCs (93\% reduction from WT levels; Figure

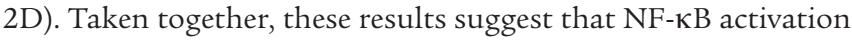


A

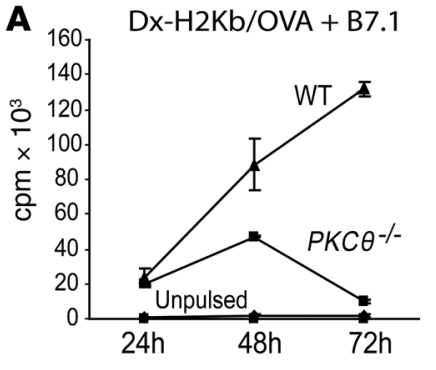

B

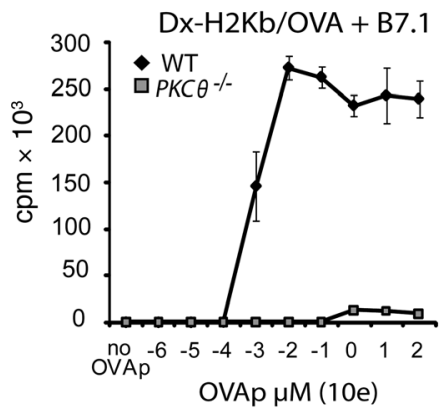

C

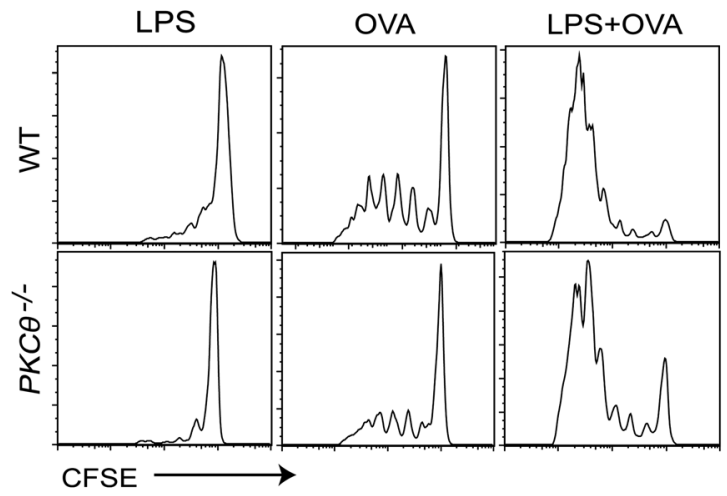

D

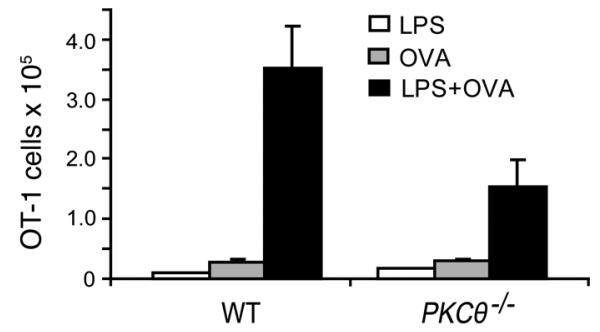

WT

G

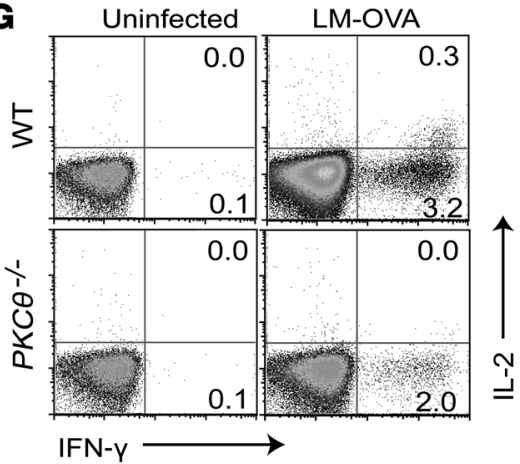

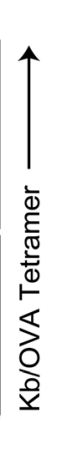

E

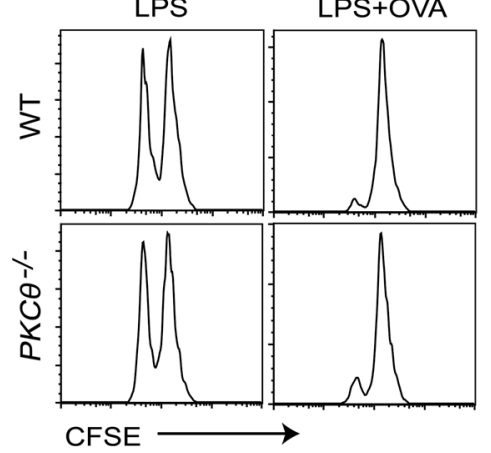

F

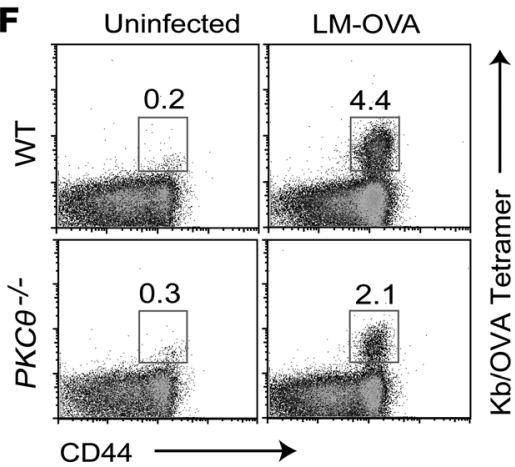

Figure 1

PKC $\theta$ is required for efficient proliferation of CD8 T cells in vitro but not in vivo. WT and PKC $\theta^{--}$OT-1 CD8 T cells were activated in vitro with microspheres bearing $\mathrm{H}-2 \mathrm{~K}^{\mathrm{b}}: \mathrm{Ig}, \mathrm{B} 7.1 \mathrm{Fc}$, and $0.1 \mu \mathrm{M}$ of $\mathrm{OVA}_{257-264}(\mathrm{OVAp})(\mathbf{A})$ or indicated $\mathrm{OVA}_{257-264}$ amounts (B). Cell proliferation (A and $\left.\mathbf{B}\right)$ was measured by ${ }^{3} \mathrm{H}$-thymidine incorporation. SD within triplicate samples is indicated. For in vivo studies, CFSE-labeled WT and $P K C \theta^{-1-}$ OT-1 T cells were transferred into C57BL/6 CD45.1 congenic recipients prior to immunization with $25 \mu \mathrm{g}$ LPS with or without $10 \mu \mathrm{g}$ OVA. Cell proliferation (C) and clonal expansion (D) of donor T cells was measured in draining lymph nodes by CFSE dilution. SD within triplicate samples is indicated in D. (E) WT and $P K C \theta^{--}$OT-1 T cells were transferred and mice immunized as in $\mathbf{C}$. 3 days later, splenocytes pulsed with $\mathrm{OVA}_{257-264}$ (CFSE $0.25 \mu \mathrm{M}$ ) or left unpulsed (CFSE $2.5 \mu \mathrm{M}$ ) were injected and monitored 10-12 hours later in the spleen by FACS. The T cell response to the OVA-expressing L. monocytogenes (LM-OVA) was measured by immunizing mice i.v. with $2 \times 10^{3} \mathrm{CFUs}$. 7 days later, clonal expansion (F) and intracellular expression of IL-2 and IFN- $\gamma(\mathbf{G})$ of activated OVA-specific CD8 T cells were measured in spleens by staining for CD8, CD44, $\mathrm{K}^{\mathrm{b}} / \mathrm{OVA}$ tetramer $(\mathbf{F})$, and $\mathrm{CD} 8$, IL-2, and IFN- $\gamma$ after a 4-hour in vitro restimulation with $100 \mathrm{nM} \mathrm{OVA} \mathrm{A}_{257-264}$ in the presence of brefeldin $\mathrm{A}(\mathbf{G})$ followed by FACS. Numbers in $\mathbf{F}$ and $\mathbf{G}$ represent percentages within spleen CD8 T cells.

in $\mathrm{T}$ cells, presumably via cell-surface costimulatory molecules or secreted products such as cytokines expressed by BMDCs, is required for rescue of $\mathrm{PKC}^{-/-} \mathrm{CD} 8 \mathrm{~T}$ cell proliferation.

To determine whether NF- $\mathrm{KB}$ activation is also sufficient for rescue of $P K C \theta^{-/-}$cell proliferation by microspheres, WT and $P K C \theta^{-/-}$ OT-1 CD8 T cells were first stimulated with microspheres coated with $\mathrm{H} 2 \mathrm{~K}^{\mathrm{b}} / \mathrm{OVA} / \mathrm{B} 7$. After 24 and 48 hours of activation, the cells were infected with a GFP-expressing retroviral construct bearing

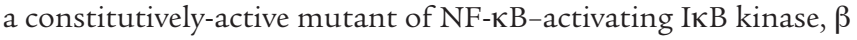

subunit (IKK $\beta$ ) kinase, which has been shown previously to be sufficient for NF-kB activation in T cells (25). Infected cells (GFP') were restimulated with $\mathrm{H} 2 \mathrm{~K}^{\mathrm{b}} / \mathrm{OVA} / \mathrm{B} 7$ microspheres for an additional 2 days. While $P \mathrm{KC}^{-/}$cells infected with the control (murine stem cell virus internal ribosome entry site GFP [MIG]) virus were unable to proliferate like WT cells (Figure $2 \mathrm{E}$ ), $\mathrm{PKC}^{-/-} \mathrm{T}$ cell proliferation was largely rescued by IKK $\beta$. These results demonstrate that activation of NF- $\mathrm{KB}$ is not only required but also largely sufficient for rescuing $\mathrm{PKC}^{-/-} \mathrm{CD} 8 \mathrm{~T}$ cell proliferation. Together, our 


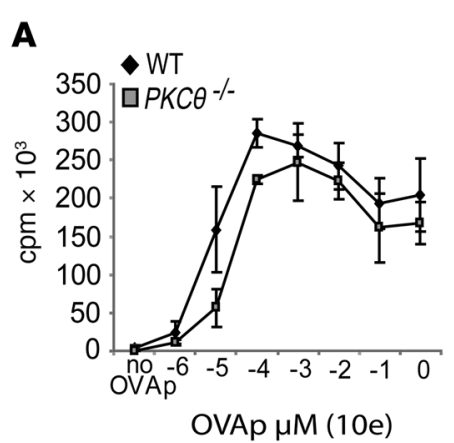

B
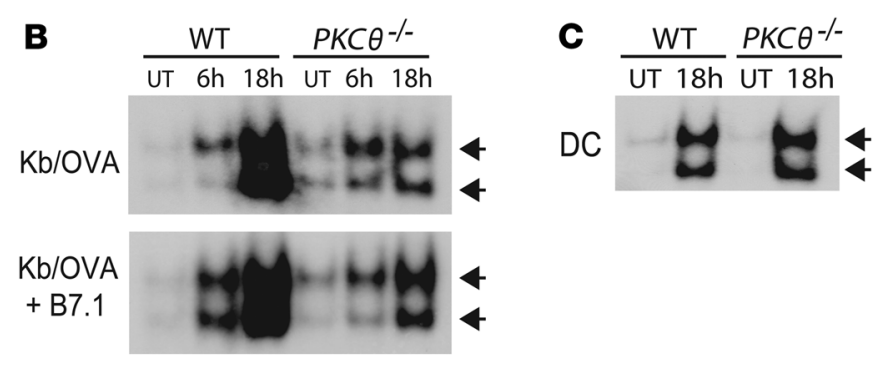

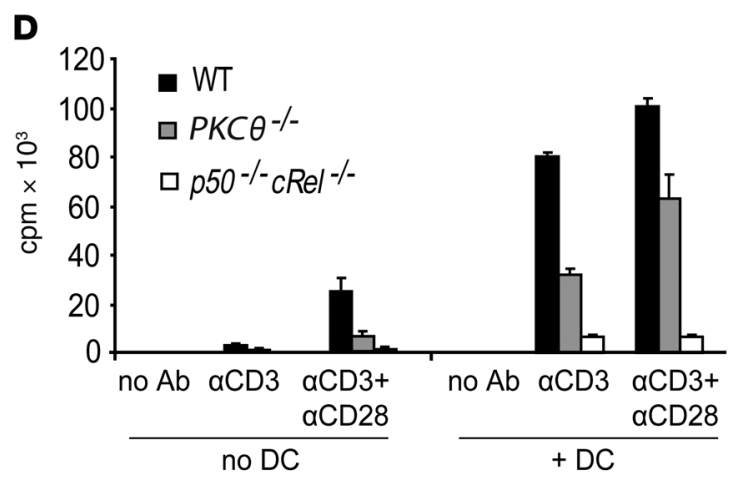

E

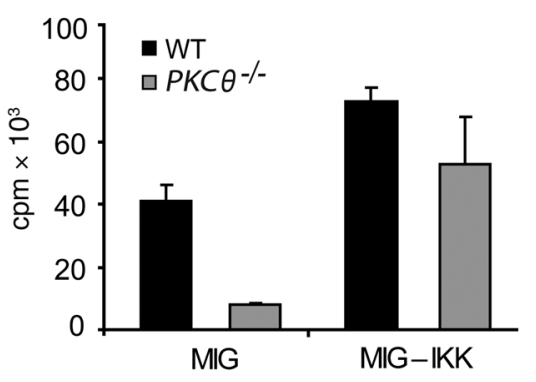

Figure 2

Crucial role of NF- $\mathrm{KB}$ in mediating PKC $\theta$-dependent and -independent responses. (A) $1 \times 10^{5}$ MACS-purified WT and PKC $\theta^{-/-}$OT- 1 CD8 T cells were stimulated with $1 \times 10^{4} \mathrm{BM}$-derived DCs in the presence of increasing amounts of OVAp ranging from $0 \mu \mathrm{M}$ to $10 \mu \mathrm{M}$, as indicated. (B) $1 \times 10^{5}$ MACS-purified WT and $P K C \theta^{-/-}$OT-1 CD8 T cells were activated with microspheres bearing DimerX H-2K $\mathrm{K}^{\mathrm{b}}: \mathrm{Ig}$ (pulsed with $0.1 \mu \mathrm{M}$ OVAp) and B7.1:Fc or (C) $1 \times 10^{4} \mathrm{BM}$-derived DCs in the presence of $1 \mu \mathrm{M}$ OVAp. Untreated (UT) samples received no stimulation. NF- $\mathrm{BB}$ nuclear localization was measured at the indicated times by EMSA. Prior to generating EMSA extracts, DCs were removed by positive selection of CD11c $\mathrm{C}^{+}$cells

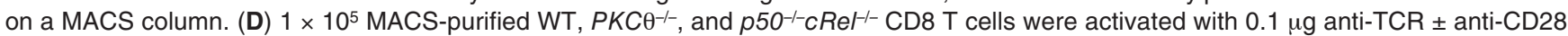
agonistic antibodies (coated on plates) in the presence or absence of $1 \times 10^{4}$ BM-derived DCs. T cell proliferation was measured after 3 days by ${ }^{3} \mathrm{H}$-thymidine incorporation. (E) $1 \times 10^{5}$ MACS-purified WT and $P K C \theta^{-/-}$OT-1 CD8 T cells were activated with microspheres coated with $\mathrm{H}-2 K^{\mathrm{b}} / \mathrm{OVA}$ plus B7.1:Fc as described above. After 24 and 48 hours of activation, the cells were infected with the GFP-expressing retroviral vectors MIG or MIG-IKK. GFP+ cells were sorted by FACS and restimulated with $\mathrm{K}^{\mathrm{b}} / \mathrm{OVA} / \mathrm{B} 7$ microspheres for an additional 48 hours. Proliferation was measured by ${ }^{3} \mathrm{H}$-thymidine incorporation during the last 10 hours of restimulation. Error bars indicate SD in triplicate samples.

results suggest that $\mathrm{NF}-\kappa \mathrm{B}$ activation by $\mathrm{PKC} \theta$-independent pathways is likely responsible for rescue of $\mathrm{PKCO}^{-/-} \mathrm{T}$ cell proliferation in vivo. Furthermore, such PKC $\theta$-independent pathways may be enhanced by microbial signals and thus explain a previously documented requirement for innate immunity (via microbial stimulation) in rescue of $P K C \theta^{-/-}$T cell proliferation $(16,26)$.

$P K C \theta$ plays a critical role in CD8 T cell-induced GVHD. In light of the above findings, we evaluated the role of PKCO in the generation of alloreactivity and GVHD, which typically does not require microbial stimulation. To this end, CD8 T cells from WT or $\mathrm{PKC} \boldsymbol{H}^{-/-}$ B6 donors were transferred into sublethally irradiated (500 cGy) $\mathrm{MHC}$ class I mismatched bm 1 recipients. In this model, donor $\mathrm{T}$ cells severely damage the hematopoietic system, resulting in marrow failure and GVHD lethality (27). As expected, WT CD8 T cells induced death of all the recipients within 20 days after cell transfer (Figure 3A). In contrast, the ability of $\mathrm{PKCO}^{-/-} \mathrm{CD} 8 \mathrm{~T}$ cells to cause GVHD lethality was severely ameliorated $(P=0.0008$; Figure $3, \mathrm{~A}$ and B). Additionally, in contrast to OVA/LPS-induced proliferation in vivo (Figure $1 \mathrm{C}$ ), $\mathrm{PKC} \mathrm{K}^{-/-} \mathrm{CD} 8 \mathrm{~T}$ cell proliferation in $\mathrm{bm} 1$ mice was significantly impaired compared with WT CD8 T cells (Figure 3C). However, homeostatic proliferation of $\mathrm{PKC}^{-/-} \mathrm{CD} 8$ $\mathrm{T}$ cells in irradiated syngeneic B6 mice was comparable to WT T cells (Supplemental Figure 2). These results therefore indicate that PKC $\theta$ plays a critical role in alloantigen-induced CD8 T cell proliferation and GVHD induction.

$P K C \theta$ is required for GVHD development in $B 6 \rightarrow B A L B / c$ BMT model. In the clinical hematopoietic cell transplantation setting, GVHD typically refers to the epithelial damage induced by donor CD4 and $\mathrm{CD} 8 \mathrm{~T}$ cells in $\mathrm{MHC}$ and/or MiHA recipients that are lethally irradiated (i.e., myeloablated) and reconstituted with hematopoietic stem cells containing peripheral $\mathrm{T}$ cells from the donor. Therefore, we next evaluated the role of PKC $\theta$ in myeloablated recipients in which GVHD lethality is induced through epithelial damage (28). CD4 and CD8 T cells were purified from WT or $\mathrm{PKC}^{-/-} \mathrm{B} 6$ mice and transferred together with WT T cell-depleted (TCD) BM cells into lethally irradiated MHC- and MiHA-mismatched BALB/c recipients. To independently evaluate the role of NF- $\mathrm{BB}$ in GVHD induction, we utilized $p 50^{-1-} \mathrm{CRel}^{-/-} \mathrm{T}$ cells, which have greatly reduced TCR-induced NF- $\mathrm{KB}$ activity (25). As expected, recipients of $2 \times 10^{6}$ WT T cells showed typical clinical features of GVHD, including hunched back, ruffled fur, hair loss, diarrhea, and body weight loss. More than $70 \%$ of WT mice died within 60 days after BMT whereas, in sharp contrast, the recipients of $\mathrm{PKC}^{-/-}$or $\mathrm{p5O}^{-/-} \mathrm{CRel}^{-/-}$ T cells did not have GVHD manifestations and survived through 

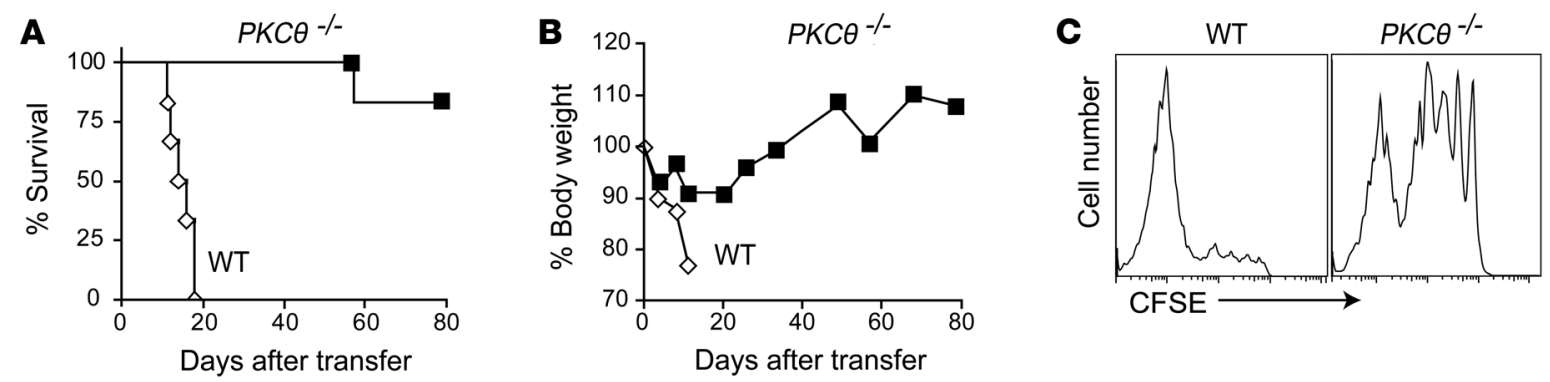

\section{Figure 3}

PKC $\theta$ plays a critical role in CD8 T cell-induced GVHD. $1 \times 10^{6}$ MACS-purified WT and PKC $\theta^{-/-}$CD 8 T cells were transferred into sublethally irradiated (500 cGy) bm1 recipients, and the recipients were monitored for survival (A) and weight loss (B). (C) 5-8 $\times 10^{6}$ MACS-purified and CFSE-labeled B6 WT or $P K C \theta^{-/-}$CD8 donor T cells were injected i.v. into sublethally irradiated bm1 recipients, and their proliferation was monitored in the spleen 4 days after transfer. Representative results from 2 separate experiments are shown.

the entire observation period (Figure 4, A and B). Together, these

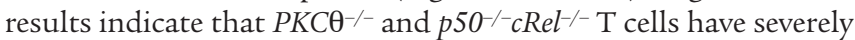
reduced ability to induce GVHD. Histopathological appearance of the small intestine of BALB/c mice injected with WT CD8 T cells showed clear evidence of GVHD including glandular destruction, lymphocytic infiltrate, and loss of mucosa compared with the unaffected intestines of mice injected with $\mathrm{PKCO}^{-/-} \mathrm{T}$ cells (Figure 4C). Donor reconstitution in the recipient was measured at 100 days after BMT, at which point recipients of $\mathrm{PKCO}^{-/-}$or $\mathrm{p5O}^{-/-} \mathrm{CRel}^{-/-} \mathrm{T}$ cells showed normal $\mathrm{T}$ and $\mathrm{B}$ cell reconstitution compared with mice of the BM alone group (Supplemental Figure 3).

We next determined whether the impaired ability of alloreactive $P K C \theta^{-/-} \mathrm{T}$ cells to cause GVHD could be attributed to a defect in $\mathrm{T}$ cell expansion. To test this, CFSE-labeled $\mathrm{T}$ cells were transferred into lethally irradiated $\mathrm{BALB} / \mathrm{c}$ recipients, and the kinetics of cell proliferation in the spleen were compared between WT and $\mathrm{PKC}^{-/-}$ T cells. Our results indicate that $P K C \theta^{-/-} \mathrm{CD} 8 \mathrm{~T}$ cells have impaired proliferation compared with WT CD8 T cells (Figure 4D). In addition, annexin $\mathrm{V}$ staining revealed greater cell death in $\mathrm{PKC}^{-/-} \mathrm{CD} 8$ T cells than in WT cells $(P=0.04$; Figure $4 \mathrm{D})$. Similar observations were made with $\mathrm{PKCO}^{-/-} \mathrm{CD} 4 \mathrm{~T}$ cells (data not shown) and were further confirmed by the significant decrease in absolute numbers of both $\mathrm{PKC}^{-/-} \mathrm{CD} 4$ and CD8 T cells (Figure 4E). Th1 responses primarily account for GVHD development (29). We next determined whether PKC $\theta$ affects $\mathrm{T}$ cell differentiation following allogeneic BMT. By measuring intracellular cytokine expression (Supplemental Figure 4), we found that a smaller percentage of $\mathrm{PKC}^{-/-} \mathrm{CD} 4$ and CD8 produced IFN- $\gamma$ compared with WT T cells but that these differences were not statistically significant $(P>0.05)$. Very few WT or $P \mathrm{KCO}^{-/-} \mathrm{T}$ cells produced IL-4 ( $<2 \%$; data not shown), indicating there was no significant Th2 response after allogeneic BMT. These results suggest that impaired ability of $\mathrm{PKC}^{-/-}$to induce GVHD more likely results from impaired activation and/or survival (Figure 4, D and E) rather than from differentiation defects.

A recent study suggested that $P K C \theta^{-/-}$accessory cells (i.e., non$\mathrm{T}$ cells) could promote cardiac graft rejection by $\mathrm{PKC}^{-/-} \mathrm{T}$ cells (30). We further asked whether whole splenocytes (i.e., containing accessory cells, including B cells and DCs) used as donor cells could induce GVHD in BALB/c recipients. As seen with T cells, splenocytes from WT but not $P \mathrm{KC}^{-/-}$donors could induce GVHD (Supplemental Figure 5). Thus, PKCO is essential for alloantigeninduced $\mathrm{T}$ cell proliferation and GVHD induction in this clinically relevant mouse BMT model.
Strength of TCR stimulation determines the requirement for PKCO in T cell activation. Based on our above findings, we hypothesized that provision of microbial stimulation may rescue proliferation of alloreactive $P \mathrm{KC}^{-/-} \mathrm{T}$ cells and GVHD induction. However, neither LPS nor CPG administration increased $P \mathrm{KC}^{-/-} \mathrm{T}$ cell-induced GVHD development or enhanced lethality (data not shown). While these results do not discount the significance of microbial agents in stimulating $\mathrm{PKC}^{-/-} \mathrm{T}$ cell responses, they suggest that additional mechanisms may account for lack of GVHD induction by $\mathrm{PKC}^{-/-}$ $\mathrm{T}$ cells, including a fundamental difference in requirement for $\mathrm{PKC} \theta$ in TCR-induced responses by self-MHC/antigen versus allo$\mathrm{MHC} /$ antigen. To address this possibility, we compared the in vitro activation of WT and $\mathrm{PKCO}^{-/-} \mathrm{CD} 8 \mathrm{~T}$ cells in response to spleen APC isolated from $\mathrm{H}-2^{\mathrm{b}}$ syngeneic $(\mathrm{C} 57 \mathrm{BL} / 6)$ versus $\mathrm{H}-2^{\mathrm{d}}$ allogeneic $(\mathrm{BALB} / \mathrm{c})$ mice (Figure 5, A and B). Importantly, allogeneic activation of $\mathrm{PKC}^{-/-}$cells was severely reduced $(\sim 10$-fold reduction from WT levels; Figure 5B) when compared with antigen-induced activation ( 2-fold or less reduction from WT levels; Figure 5A).

Since the activation/maturation state of syngeneic and allogeneic $\mathrm{APC}$ used here is the same, the underlying difference in $\mathrm{PKC} \theta$ requirement likely lies in TCR-induced signals. A key difference between these 2 systems is that the response of OT-1 T cells involves high-affinity interactions between monoclonal TCR and self-MHC/peptide. In contrast, allogeneic proliferation involves activation of $\mathrm{T}$ cells bearing TCRs with a wide range of affinities for different allo-MHC/antigens. Furthermore, lower affinity interactions between TCR and allo-MHC/ antigen play a crucial role in GVHD induction $(31,32)$. Thus, a possible explanation for impaired allogeneic proliferation of $\mathrm{PKC}^{-/-} \mathrm{T}$ cells may be that they respond poorly to lower affinity TCR agonists.

We next examined the role of dose and affinity on alloreactive $\mathrm{PKC}^{-/-} \mathrm{T}$ cell proliferation using $2 \mathrm{C} \mathrm{Tg}$ mice. The CD8 2C TCR is positively selected in $\mathrm{H}-2 \mathrm{~K}^{\mathrm{b}}$ mice and negatively selected in $\mathrm{H}-2 \mathrm{~L}^{\mathrm{d}}$ mice (e.g., BALB/c mice) $(33,34)$. $2 \mathrm{C} \mathrm{Tg} \mathrm{T} \mathrm{cells} \mathrm{recognize} \mathrm{the} \mathrm{natu-}$ rally occurring $\mathrm{p} 2 \mathrm{Ca}$ peptide presented by $\mathrm{H}-2 \mathrm{~L}^{\mathrm{d}}$ with high affinity (35). A variant of $\mathrm{p} 2 \mathrm{Ca}$ (QL9 peptide) binds 2C TCR with 10-fold greater affinity when complexed with $\mathrm{H}-2 \mathrm{~L}^{\mathrm{d}}(36) . P K C \theta^{-/-} 2 \mathrm{C} \mathrm{Tg} \mathrm{T}$ cells can therefore allow us to study the role of TCR-MHC/peptide interaction affinity on $\mathrm{T}$ cell activation. Using BMDCs from $\mathrm{BALB} / \mathrm{c} \times \mathrm{B} 6 \mathrm{~F} 1$ mice (CB6), we determined the role of both affinity and antigen dose on $P K C \theta^{-/-} 2 \mathrm{C}$ T cell activation. WT $2 \mathrm{C}$ T cells proliferated strongly when cocultured with CB6 BMDCs through endogenously expressed $\mathrm{p} 2 \mathrm{Ca}$ by these BMDCs (Figure 5C). WT $2 \mathrm{C} \mathrm{T}$ cell proliferation was enhanced in the presence of $1 \mu \mathrm{M}$ or 

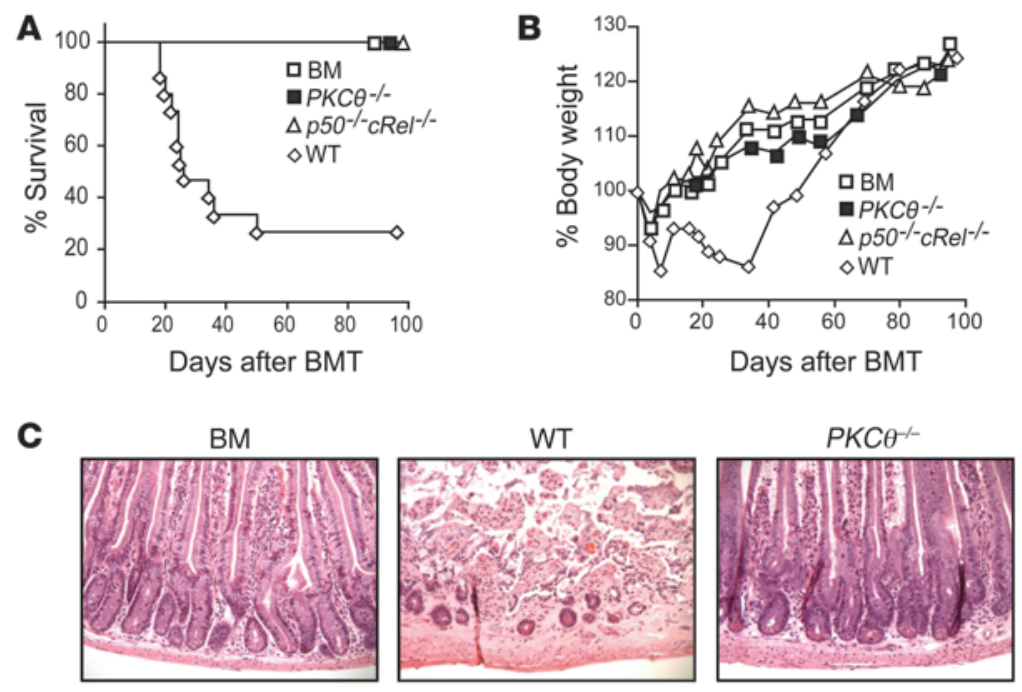

D
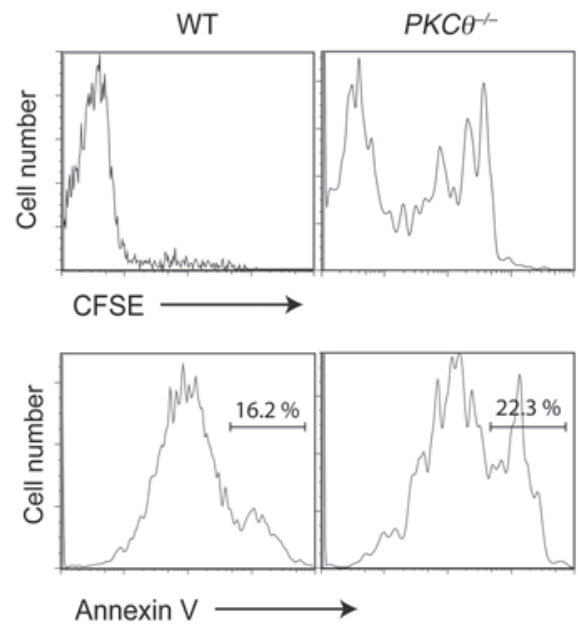

E
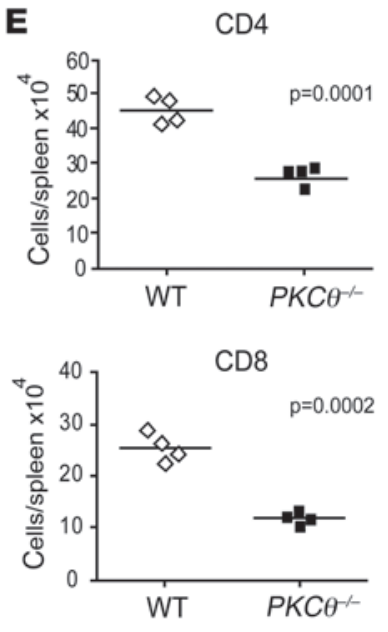

\section{Figure 4}

PKC $\theta$ is required for GVHD development in a B6 $\rightarrow$ BALB/c BMT model. $2 \times 10^{6}$ MACS-purified B6 WT, $P K C \theta^{-/-}$, or NF-кB p50 ${ }^{-/-} \mathrm{CRel}^{-/-} \mathrm{CD} 4^{+}$and $\mathrm{CD}^{+}$donor $\mathrm{T}$ cells were injected i.v. into lethally irradiated (800-900 cGy) BALB/c recipient mice along with $\mathrm{T}$ cell-depleted BM (BM). Recipients were monitored 2-3 times weekly for clinical signs of GVHD and survival (A) and weight loss (B). Animals that were moribund were sacrificed and counted as GVHD mortality. H\&E staining of the gut epithelium was performed approximately 20 days after $\mathrm{T}$ cell transfer $(\mathbf{C})$. Original magnification, $\times 200$. The initial proliferation and survival of donor CD8 T cells was measured by transferring CFSElabeled cells and staining for $\mathrm{CFSE}^{+} \mathrm{CD}^{+} \mathrm{H}-2^{\mathrm{b}+}$ annexin $\mathrm{V}^{+}$cells 4 days after transplantation (D). Donor $T$ cell expansion was measured by staining for $\mathrm{CD}^{+}{ }^{+} \mathrm{H}-2^{\mathrm{b}+}$ and $\mathrm{CD}^{+} \mathrm{H}-2^{\mathrm{b}+}$ cells in the spleen 4 days after transplantation (E). Horizontal bars indicate the averages of 4 mice in each group.

gated whether $\mathrm{PKC}^{-/-} 2 \mathrm{C}$ T cells are similarly unable to expand in vivo. In this model, sublethally irradiated CB6 mice are injected with donor $2 \mathrm{C} \mathrm{T}$ cells, which severely damage the recipient hematopoietic system, especially B cells (39). Peripheral blood from WT 2C T cell-injected CB6 mice showed that numbers of these $\mathrm{T}$ cells peaked on day 14 (Figure 6A). In contrast, $P \mathrm{KC}^{-/-} 2 \mathrm{C} \mathrm{T}$ cell numbers were significantly reduced on days 14 and $22(P<0.05$; Figure 6A). As expected from low $\mathrm{T}$ cell numbers, substantial recipient $B$ cell reconstitution was observed in $\mathrm{PKCO}^{-/-} 2 \mathrm{C}$ T cell recipients but not in WT 2C T cell recipients $(P<0.01$; Figure 6B). Thus, impaired expansion of $\mathrm{PKCO}^{-/-} 2 \mathrm{C} \mathrm{T}$ cells allows robust recipient $\mathrm{B}$ cell reconstitution in this sublethal irradiation model. Next,

$10 \mu \mathrm{M}$ exogenously added $\mathrm{p} 2 \mathrm{Ca}$. In notable contrast, $\mathrm{PKC} \mathrm{C}^{-/-}$ $2 \mathrm{C} \mathrm{T}$ cells showed greatly reduced proliferation in the presence of endogenous p2Ca presented by BMDCs (Figure 5C). However, this was partially rescued by high levels of exogenous peptide (e.g., $10 \mu \mathrm{M}$ p2Ca). Thus, while $P K C \theta^{-/-} 2 \mathrm{C}$ T cells can respond well to higher concentrations of $\mathrm{p} 2 \mathrm{Ca}$ peptide, the amount of naturally expressed $\mathrm{p} 2 \mathrm{Ca}$ by APC is apparently insufficient to support proliferation of $\mathrm{PKCO}^{-/-} 2 \mathrm{C}$ T cells. In the presence of the higher affinity QL9 peptide, $\mathrm{PKCO}^{-/-}$2C T cells proliferated strongly at both $1-\mu \mathrm{M}$ and $10-\mu \mathrm{M}$ peptide concentrations (Figure 5D). Similar to that of $P K C \theta^{-/-} 2 \mathrm{C}$ T cells, $P K C \theta^{-/-}$OT-1 T cell proliferation was more severely impaired in response to low-affinity peptide agonists SIIGFEKL (G4) and EIINFEKL (E1) $(37,38)$ than to the high-affinity SIINFEKL peptide, relative to WT OT-1 T cells (Supplemental Figure 6). Collectively, these observations suggest that insufficient expression and/or affinity of allo-MHC/peptide complexes may be responsible for the inability of $\mathrm{PKC}^{-/-} \mathrm{T}$ cells to undergo robust expansion in allogeneic settings.

Essential requirement for $P K C \theta$ in 2C T cell expansion and cytotoxicity in vivo. Our in vitro studies demonstrate the inability of $\mathrm{PKC}^{-/-}$ $\mathrm{T}$ cells expressing the $2 \mathrm{C} \mathrm{Tg}$ to undergo robust proliferation in response to naturally expressed $\mathrm{p} 2 \mathrm{Ca}$ antigen. We next investi- we determined the effect of microbial/inflammatory agents on $\mathrm{PKC}^{-/-} 2 \mathrm{C} \mathrm{T}$ cell expansion. Recent studies indicate that a combination of TLR ligands and agonistic anti-CD40 Abs (FGK45) provide an exceptionally strong signal for $\mathrm{T}$ cell proliferation (40-42). Furthermore, studies have shown that TLR ligands can exacerbate GVHD (43). We employed the TLR3 ligand poly(I:C) (a synthetic dsRNA mimic) and anti-CD40 to stimulate proliferation of $P \mathrm{KC}^{-1-} \mathrm{T}$ cells. A single treatment with anti-CD40 plus polyI:C enhanced expansion of WT 2C $(P<0.02$ at all 3 time points $)$ and elimination of host $\mathrm{B}$ cells $(P=0.01$ on day 6 ; Figure $6 \mathrm{~B}) . P K C \theta^{-/-}$ $2 \mathrm{C}$ T cells showed enhanced expansion at days 14 and 22 in the presence of anti-CD40 plus polyI: $\mathrm{C}$, although the differences were not significant $(P>0.05$; Figure $6 \mathrm{~A})$. Furthermore, $\mathrm{B}$ cell reconstitution was significantly decreased in the recipients of $P \mathrm{KC}^{-/-} 2 \mathrm{C}$ T cells when anti-CD40 plus poly(I:C) was administered $(P<0.01$ at all 3 time points). Overall, these results indicate that the presence of strong microbial/inflammatory agents can enhance but is insufficient to fully rescue $P K C \theta^{-/-} 2 \mathrm{C}$ T cell expansion.

$P K C \theta^{-/-}$T cells can mount an effective anti-murine CMV response after $B M T$. Allogeneic BMT results in increased risk of life-threatening infections. The above findings (Figure 1) and previous studies show that responses to bacterial and viral agents remain intact in 

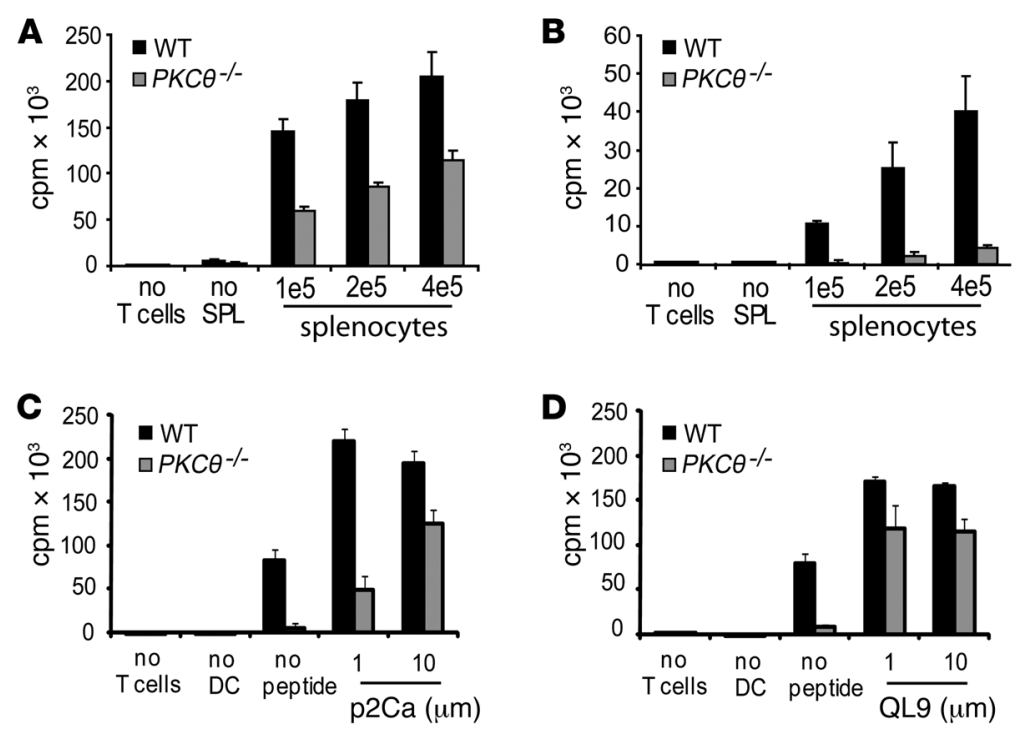

\section{Figure 5}

Strength of TCR stimulation determines the requirement for PKC $\theta$ in T cell activation. $1 \times 10^{5}$ MACS-purified Tg WT OT-1 and PKC $\theta^{-1-}$ OT-1 CD8 T cells $(\mathbf{A})$ or WT and $P K C \theta^{-1-}$ CD8 T cells (B) were stimulated with increasing amounts of whole irradiated splenocytes from syngeneic C57BL/6 (A) or allogeneic BALB/c (B) mice. Syngeneic APCs were cocultured with OT-1 responders in the presence of $1 \mu \mathrm{M} \mathrm{OVA}_{257-264}$ peptide. To measure proliferation induced by different affinity peptides, CB6 BM-derived DCs $\left(1 \times 10^{4}\right)$ were cultured with WT or $\mathrm{PKC}^{-/-} 2 \mathrm{C} \mathrm{CD} 8 \mathrm{~T}$ cell responders in the presence of indicated amounts of p2Ca (C) or QL9 (D) peptides. $\mathrm{T}$ cell proliferation was determined 3 days later by ${ }^{3} \mathrm{H}$-thymidine incorporation. Representative results from 2 separate experiments are shown. Error bars indicate $\mathrm{SD}$ in triplicate samples. the absence of PKCO (26). Similar to these studies, $P K C \theta^{-/-}$mice mounted comparable murine CMV-specific (MCMV-specific) $\mathrm{T}$ cell responses to WT mice, and viral clearance was only slightly reduced in $\mathrm{PKCO}^{-/-}$mice (data not shown). How absence of PKC $\theta$ has an impact on responses against infectious agents following BMT is not clear. To this end, we used an MCMV infection model $(44,45)$. CMV is one of the most common infections in BMT patients (46) and thus a highly relevant infectious agent for these studies. 60 days after WT and $P K C \theta^{-/-}$BM transfer into lethally irradiated $\mathrm{CB} 6$ recipients, comparable numbers of MCMV tetramer-positive cells were generated 10 days after infection (Figure 7A). Furthermore, clearance of MCMV was comparable in WT and $P \mathrm{KC}^{-/-} \mathrm{BM}$-transplanted mice (Figure $7 \mathrm{~B}$ ). For both tetramer analysis and virus titer, BM-transplanted mice were also sacrificed on day 3 , at which point there is minimal $\mathrm{T}$ cell activation or virus clearance (Figure 7, A and B). Inclusion of $5 \times 10^{6} \mathrm{WT}$ splenocytes results in mild GVHD in this mouse model, which typically reduces responses to infectious agents. Consistent with this and our previous results showing lack of GVHD by $\mathrm{PKC}^{-/-}$splenocytes (Supplemental Figure $5)$, recipients of the WT splenocyte group showed significantly fewer tetramer-positive cells than recipients of $P \mathrm{KCO}^{-/-}$splenocytes $(P=0.03$; Figure $7 \mathrm{~A})$. Although not statistically significant, recipients of WT splenocytes showed higher MCMV load than recipients of $\mathrm{PKC}^{-/-}$splenocytes (Figure 7B). Importantly, the viral load in each group on day 10 was significantly lower than that on day 3 after infection $(P<0.05)$, except in the group transplanted with BM plus WT splenocytes $(P=0.19)$. Thus, absence of PKC $\theta$ does not appear to have a substantial impact on responses to MCMV infection after BMT.

Preservation of GVL responses in the absence of PKCO in T cells. When BMT is used as therapy for hematologic malignances, an important role for donor $\mathrm{T}$ cells is to pre- vent relapse of original disease through GVL effects. Therefore, it is critically important to determine whether T cells lacking PKC $\theta$ retain the beneficial GVL effect. To this end, we performed studies using the $\mathrm{B} 6 \rightarrow \mathrm{BALB} / \mathrm{c}$ BMT model and the A20 B cell lymphoma line that was retrovirally transduced with a luc/neo plasmid (28). The ability of WT and $\mathrm{PKCO}^{-/-} \mathrm{T}$ cells was compared in the induction of GVHD and in mediating GVL. To quantitatively compare WT or $P \mathrm{KCO}^{-/-} \mathrm{T}$ cells, we used 3 different cell doses: $0.5,2.0$, or $5 \times 10^{6}$ per recipient. Mortality due to GVHD or tumor relapse was distinguished as described in Methods. As expected, all recipients of TCD BM survived without A20 cell infusion. However, when A20 cells were infused, all recipients of TCD BM died within 35 days (Figure 8, A and B) without weight loss (Figure 8, C and D) but with very strong bioluminescent imaging (BLI) signals prior to death (Figure 8, E-H), indicating that tumor growth was the cause of mortality. WT T cells induced severe GVHD in a dose-dependent manner, reflected by high lethality (Figure 8A) and significant weight loss (Figure 8C) but little or no BLI signals prior to
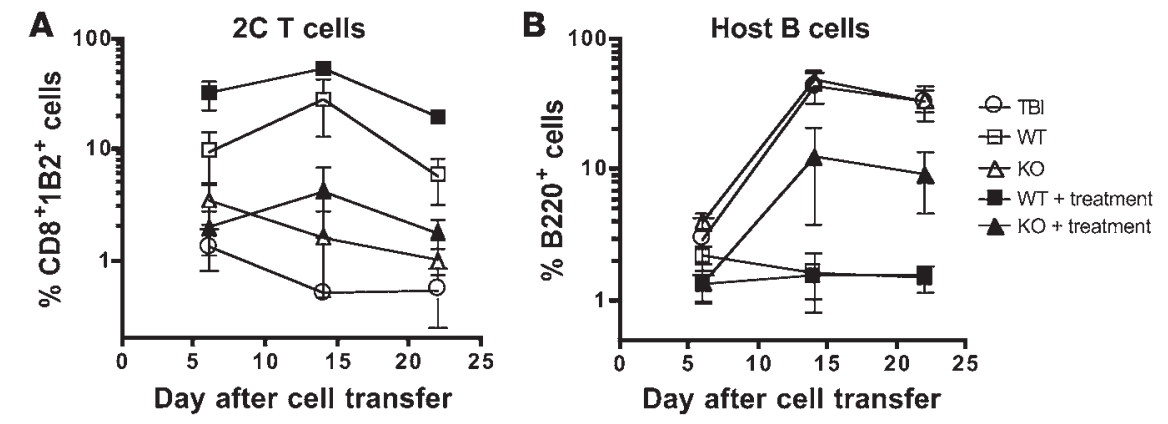

\section{Figure 6}

Essential requirement for $\mathrm{PKC} \theta$ in $2 \mathrm{C}$ T cell expansion and cytotoxicity in vivo. (A) $5 \times 10^{6}$ WT and $P K_{C} \theta^{-/-}(\mathrm{KO}) 2 \mathrm{C} \mathrm{T}$ cells were injected into sublethally irradiated $\mathrm{CB} 6$ recipient mice (3-4 mice per group). Percentages of 2 C T cells in peripheral blood 6, 14, and 22 days after T cell transfer are shown. Some mice also received $50 \mu \mathrm{g}$ anti-CD40 and $100 \mu \mathrm{g}$ poly(I:C) after irradiation as indicated (treatment). (B) Host B cell reconstitution was evaluated on different days after $T$ cell transfer as indicated. TBI, total body irradiation. Error bars indicate the SD of 3-4 mice in each group at each time point. 

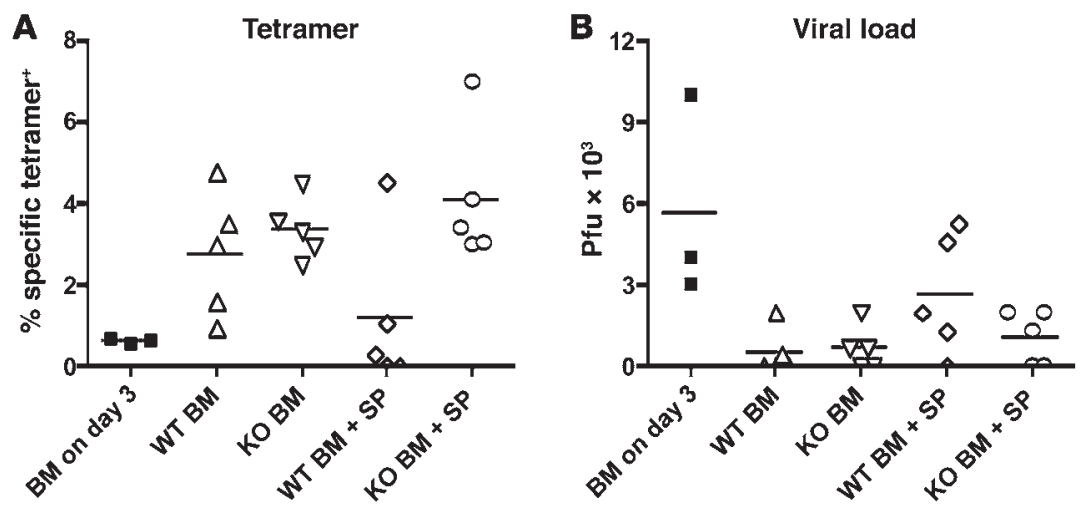

\begin{abstract}
Figure 7
$P K C \theta^{--}$T cells can mount an effective anti-MCMV response after BMT. Lethally irradiated $\mathrm{CB} 6$ recipients were transplanted with WT or $\mathrm{PKC}^{-/-}(\mathrm{KO})$ TCD BM alone or with $5 \times 10^{6}$ splenocytes from WT or KO donors, respectively. 60 days after BMT, recipients were infected with $\mathrm{MCMV}$, and $\mathrm{MCMV}$ tetramer-positive CD8 T cell numbers were determined after 10 days (A). Virus titers (B) were measured in recipient livers 10 days after infection. A few mice receiving $B M$ alone were sacrificed on day 3 after infection to determine both tetramerpositive cells and virus titer in livers as indicated (BM on day 3). Horizontal bars indicate the averages of 3-5 mice in each group.
\end{abstract}

death (Figure 8, E and G). In contrast, all recipients of $\mathrm{PKC}^{-/-}$ $\mathrm{T}$ cells survived through the 50 -day observation period (Figure $8 \mathrm{~B}$ ) with mild to modest body-weight loss (Figure $8 \mathrm{D})$. Furthermore, all the recipients of $5 \times 10^{6} \mathrm{KO}$ cells and most recipients of $0.5(80 \%)$ or $2.0 \times 10^{6}(60 \%) \mathrm{KO}$ cells had little or no BLI signal (Figure $8, \mathrm{~F}$ and $\mathrm{H})$, indicating these recipients were largely free from tumor. The average signal intensity was 50 - to 100 -fold lower in recipients of TCD BM plus $P K C \theta^{-/-}$T cells than in TCD BM alone (Figure 8, F and $\mathrm{H}$ ). Most importantly, none of the recipients that were transplanted with $P \mathrm{KCO}^{-/-} \mathrm{T}$ cells died within the observation period (Figure $8 \mathrm{~B}$ ). Because $5 \times 10^{6} \mathrm{PKC}^{-/-} \mathrm{T}$ cells did not induce GVHD lethality whereas $0.5 \times 10^{6}$ WT cells induced 50\% GVHD lethality (Figure 8, A and B), the ability of T cells to induce GVHD is likely more than 10 -fold lower in the absence of PKC $\theta$. Additionally, because $5 \times 10^{6} \mathrm{PKC}^{-/-} \mathrm{T}$ cells were as capable as $2.0 \times 10^{6}$ WT cells in eradicating tumor cells (Figure 8, E and F), the ability of T cells to induce GVL is likely approximately 2.5 -fold lower in the absence of PKC $\theta$. These results indicate that absence of PKC $\theta$ impacts GVHD more severely than GVL responses.

\section{Discussion}

We show here that PKC $\theta$ is not required for $\mathrm{T}$ cell responses triggered by Listeria infection or following administration of antigen with a microbial adjuvant. In contrast, we demonstrate an essential requirement for PKC $\theta$ in alloreactivity and GVHD. Using 3 distinct mouse models of alloreactivity, we show that $\mathrm{T}$ cells lacking PKC $\theta$ are unable to undergo robust expansion and cause damage to recipient hematopoietic or epithelial tissues. Importantly, $P K C \theta^{-/-} \mathrm{T}$ cells retain both $\mathrm{GVL}$ and antiinfection functions after BMT. These findings validate PKC $\theta$ as a potentially unique therapeutic target that is required for detrimental but not beneficial functions of donor T cells after BMT.

Our results indicate that $\mathrm{NF}-\kappa \mathrm{B}$ must be activated by $\mathrm{PKC} \theta$ following TCR engagement or, in the absence of $\mathrm{PKC} \theta$, through compensatory signals (e.g., costimulatory molecules) expressed on APC. These results suggest that activation of NF- $\mathrm{KB}$ through $\mathrm{PKC} \theta$-independent pathways likely rescues activation of $\mathrm{PKC}^{-/-} \mathrm{T}$ cells in vivo. Previous studies indicated a role for innate $/$ microbial signals in compensating for the absence of PKC $\theta(16,26)$. Since these signals enhance costimulatory molecule expression, it is likely that innate immunity functions by enhancing NF- $\kappa B$ activation in $P \mathrm{KCO}^{-/-} \mathrm{T}$ cells. Based on this reasoning, we determined whether impaired alloreactivity of $P K C \theta^{-/-} \mathrm{T}$ cells results from insufficient stimulation of innate immunity. However, our results suggest that the presence of microbial signals (e.g., LPS, CpG, or polyI:C plus anti-CD40) cannot fully rescue alloreactivity of $P K C \theta^{-/-} \mathrm{T}$ cells. Instead, our results indicate that a main reason for lack of GVHD is the intrinsic inability of $\mathrm{PKC}^{-/-} \mathrm{T}$ cells to undergo a strong activation response after stimulation with allogeneic $\mathrm{APC}$. In studies with $2 \mathrm{C} \mathrm{Tg}$ mice, we demonstrated that endogenous levels of alloantigens are insufficient to induce robust $P \mathrm{KCO}^{-/-} \mathrm{T}$ cell proliferation. Collectively, our results indicate that while PKC $\theta$ is not absolutely required for $\mathrm{T}$ cell activation and proliferation, it is critical when $T$ cells are activated by low antigen levels and/or low-affinity antigens (also see below). Thus, PKC $\theta$ functions in lowering the overall signaling threshold required for $\mathrm{T}$ cell activation.

Alloreactivity is generated following interaction between TCRs with varying affinities for different allo-MHC/antigens. Indeed, lower affinity interactions between TCR and allo-MHC/antigen are more important for GVHD induction than the highest affinity interactions $(31,32)$. This is in contrast to $T$ cell responses against infectious agents, which are typically dominated by high-affinity interactions with immunodominant antigen epitopes. While our results indicate that impaired alloreactivity of $\mathrm{PKC}^{-/-} \mathrm{T}$ cells is likely due to inefficient TCR-induced stimulation, TCR-independent pathways (e.g., microbial/inflammatory agent-induced enhancement of costimulation) may nonetheless also play a role. However, enhancement of APC function by these agents was not sufficient to rescue proliferation of $\mathrm{PKCO}^{-/-} \mathrm{T}$ cells stimulated by low antigen levels or low-affinity antigens. A possible reason for this may be because non-TCR signals fail to induce sufficient NF- $\mathrm{B}$ activation in $\mathrm{PKC}^{-/-} \mathrm{T}$ cells stimulated by low-level/affinity antigens. Thus, inadequate overall levels of NF- $\mathrm{KB}$ may be responsible for impaired alloreactivity of $P K C \theta^{-/-} \mathrm{T}$ cells. Consistent with this, we have shown that NF- $\mathrm{BB}$ (p50 plus cRel) is independently required for GVHD induction. Tregs can suppress GVHD induction (47). In contrast to conventional T cells, PKCO is required for the development of Tregs in the thymus but dispensable for their suppressive function (48). To exclude the contribution of Tregs, e.g., because of differences in Treg numbers between WT and $\mathrm{PKC}^{-/-}$mice, we removed Tregs $\left(\mathrm{CD}^{+} \mathrm{CD}^{2} 5^{+}\right)$from donor $\mathrm{T}$ cell populations in our studies. Thus, the precise role of $\mathrm{PKC} \theta$ in regulating Treg function after BMT remains to be determined.

After allogeneic BMT, the recipient relies on donor immune reconstitution to fight against infection. $P \mathrm{KCO}^{-/-} \mathrm{T}$ cells are impaired in the induction of GVHD but allow donor engraftment and immune reconstitution of the host (Figure 4 and Supplemental Figure 3). Using MCMV infection, we show that 

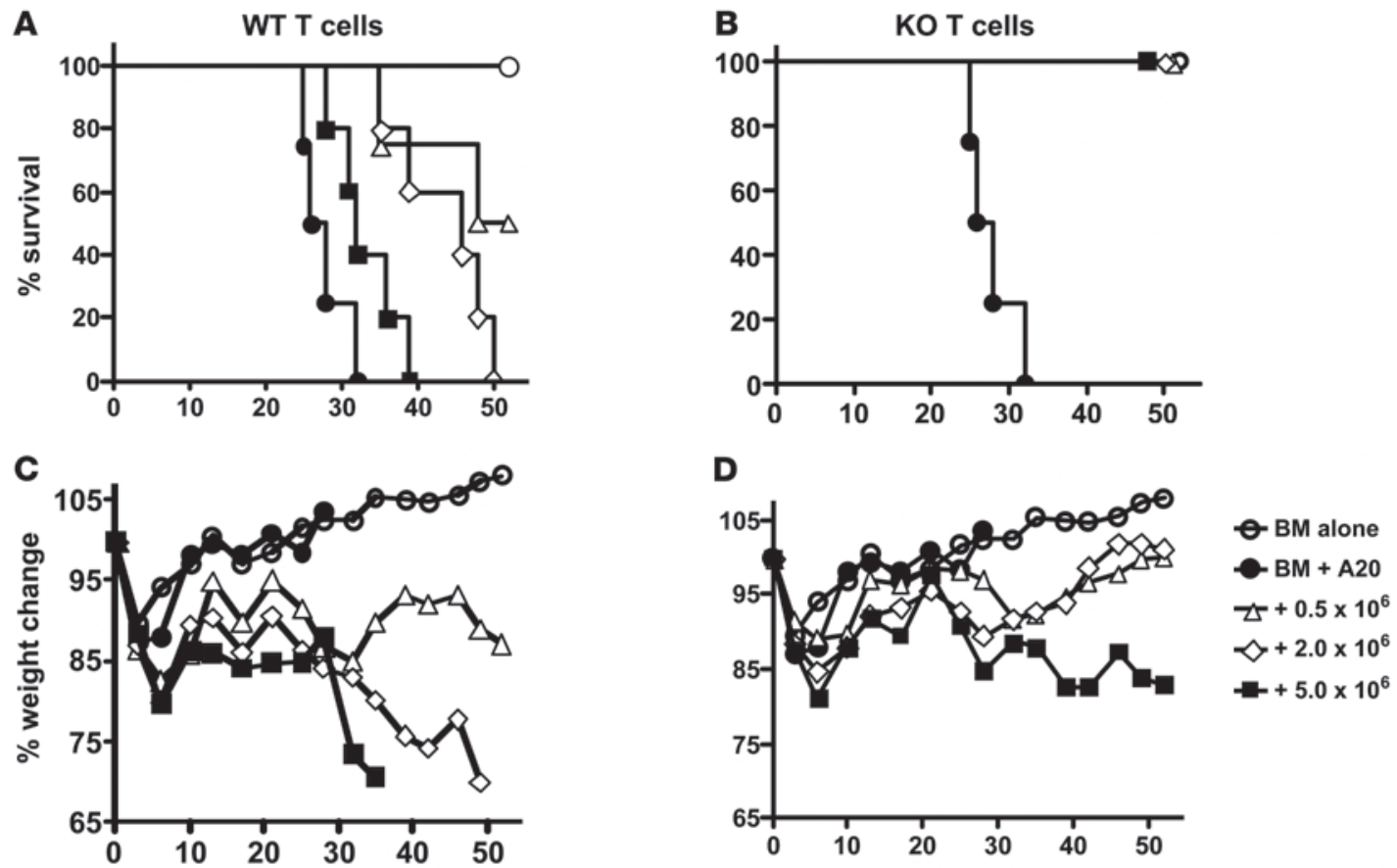

E

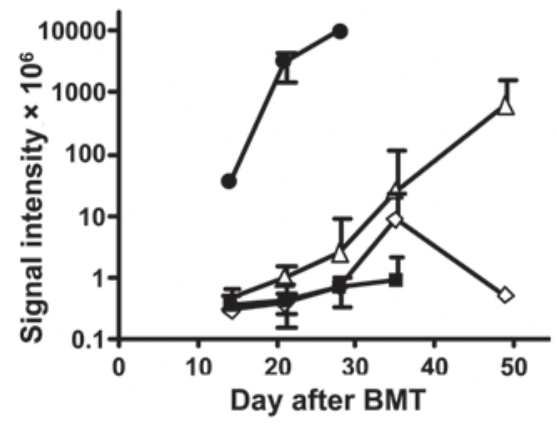

G
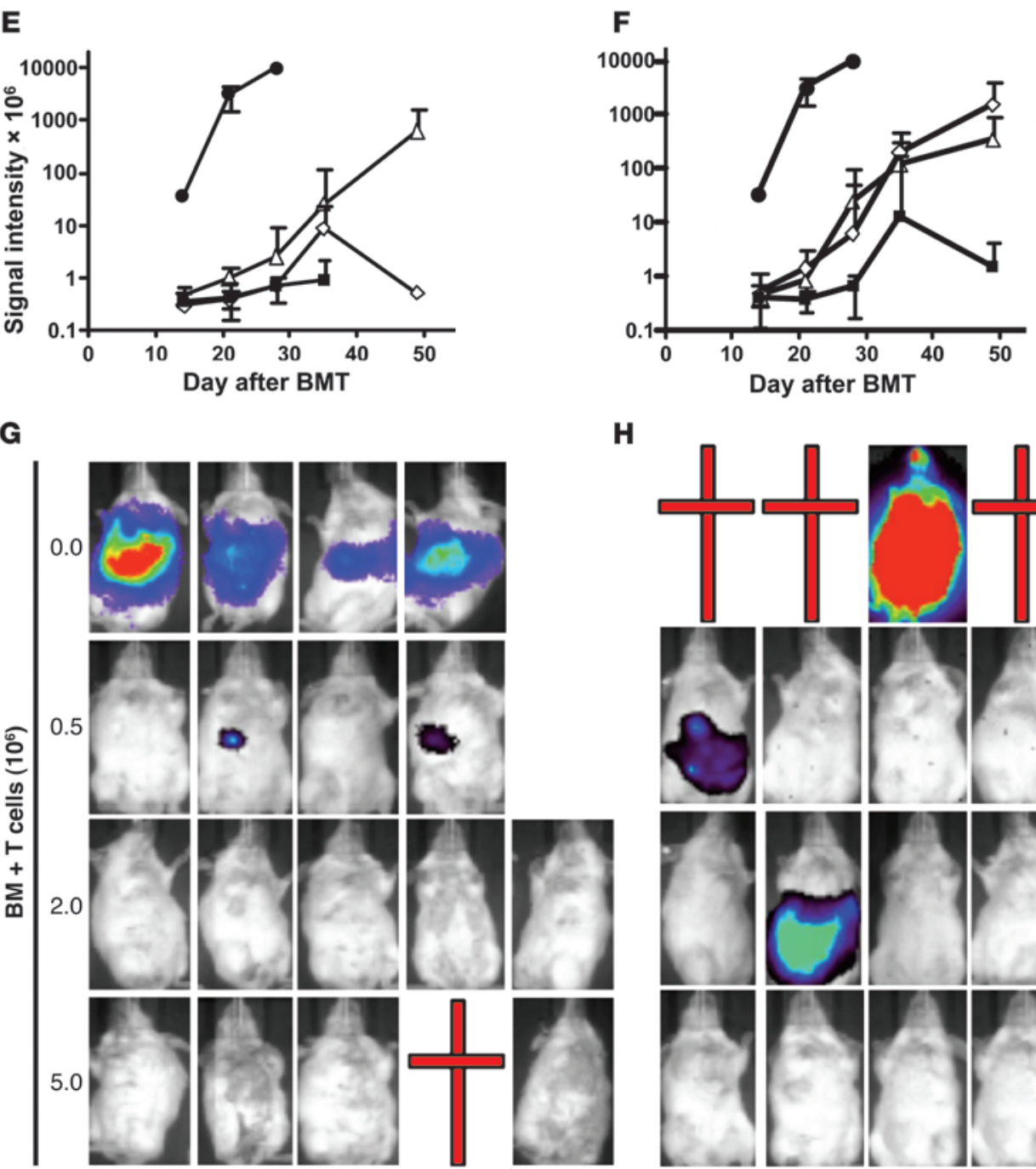

H

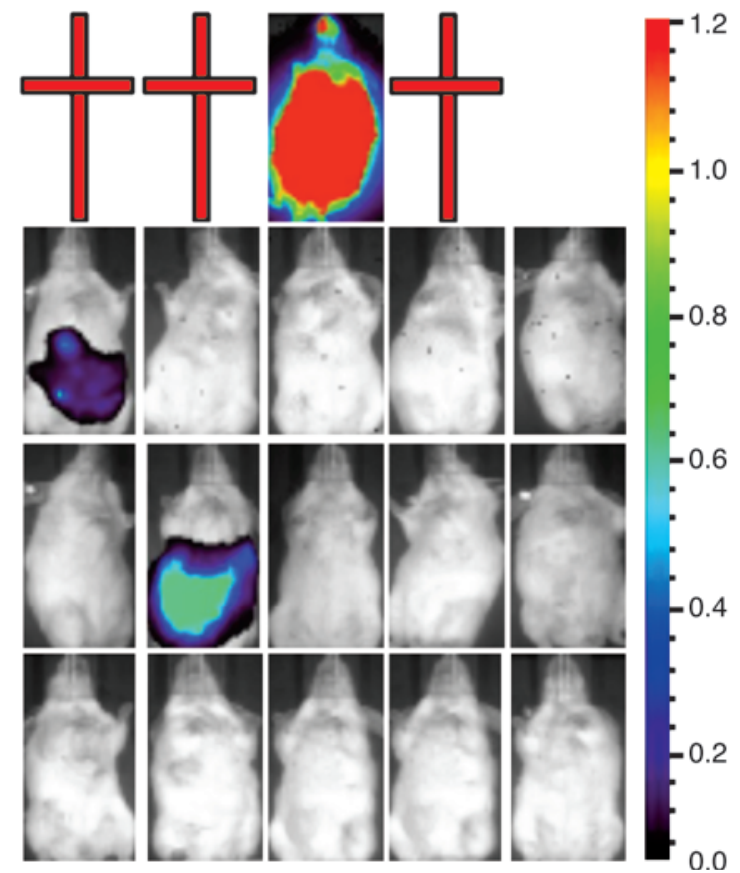




\section{Figure 8}

Preservation of GVL responses in the absence of $\mathrm{PKC} \theta$ in $\mathrm{T}$ cells. Lethally irradiated BALB/c mice were transplanted with B6 TCD BM alone or with purified T cells $\left(0.5,2.0\right.$, or $\left.5.0 \times 10^{6}\right)$ from WT or $P K C \theta^{-/-}$ (KO) B6 mice. All recipients, except those of TCD BM alone, were also given luciferase-transduced A20 cells $\left(2 \times 10^{3}\right)$ at the same time as BM cells. The TCD BM recipients are shown in both WT and KO groups (A-F) for direct comparison. Survival and body weight of the recipients that were transplanted with WT (A and $\mathbf{C})$ or KO T cells (B and $\mathbf{D})$ was followed over time after BMT. The summary of BLI signal intensity in WT $(E)$ or KO $(\mathbf{F})$ recipients are shown at multiple time points after BMT. The data present geometric mean \pm 1 SEM. The BLI signal of individual recipients of WT $(\mathbf{G})$ or $\mathrm{KO}(\mathbf{H})$ T cells is shown 28 days after BMT, except that the images in the top row $(\mathbf{G})$ were obtained from recipients of $\mathrm{BM}$ alone on day 21 . The numbers $(0.0,0.5,2.0$, and 5.0$)$ on the left $(\mathbf{G})$ indicate the number of T cells $\left(\times 10^{6}\right)$ transplanted per recipient. The pseudo color indicates the relative signal strength for tumor growth, with strongest in red and weakest in purple. Number of recipients was 5 in all the groups, except 4 in the groups of TCD BM alone and TCD BM plus $0.5 \times 10^{6}$ WT T cells. The data represent 1 of 2 replicate experiments. Crosses indicate death of mice.

$P \mathrm{KC}^{-/-} \mathrm{T}$ cells derived from $\mathrm{PKC} \mathrm{C}^{-/-} \mathrm{BM}$ can expand in response to MCMV infection, and this agent was cleared in these mice comparably to the way it was cleared in mice reconstituted with WT BM (Figure 7). These findings indicate that targeting PKC $\theta$ can prevent GVHD without compromising the ability of BMT recipients to respond to infectious agents.

When BMT is used as immunotherapy for hematopoietic malignances (e.g., leukemia), it is critically important to prevent GVHD development and tumor relapse. Despite the widely appreciated magnitude of this problem, no clinical strategy has been established to selectively prevent GVHD while preserving GVL effects. We found that the $\mathrm{PKCO}^{-/-} \mathrm{T}$ cells ranging from 0.5 to $5.0 \times 10^{6} /$ mouse did not induce GVHD lethality and protected the majority of the recipients from tumor relapse (Figure 8). We believe that targeting PKC $\theta$ represents a better strategy for reduction of GVHD and preservation of GVL than other previously described strategies, including targeting adhesion molecules and chemokine pathways. Targeting adhesion molecules including $\beta 2$ or $\beta 7$ integrin have been used to separate GVHD and GVL effects by limiting $\mathrm{T}$ cell migration. However, inhibition of GVHD was less profound than targeting PKCO in the current study $(28,49,50)$. Chemokine signals also contribute to the development of both GVHD and GVL, but targeting a single chemokine receptor (e.g., CCR1, CCR2, or CCR6) typically only partially prevents GVHD, presumably because of functional redundancy (51-53). Antiinfection activity has rarely been studied together with GVHD and GVL following $\mathrm{BMT}$. Importantly, our data indicate that targeting $\mathrm{PKC} \theta$ will have the substantial additional advantage of preserving antiinfection activity, which can further benefit patients after allogeneic BMT.

Clinical BMT recipients include individuals mismatched in either MiHA or MHC from the donor. It is well known that MHC is a stronger stimulus for $\mathrm{T}$ cell activation than MiHA. Although we have not specifically examined the role of PKC $\theta$ in an MiHA setting, the dependence of $P K C \theta^{-/-}$T cells on strong TCR stimulation suggests that their response to MiHA will be similarly or even more significantly diminished than the response to MHC. Importantly, MHC-mismatched transplantation, especially using cord blood, is being increasingly performed in the clinic (54-56). Thus, the ability to prevent GVHD, e.g., by inhibiting
PKC $\theta$ (see below), in an MHC/HLA mismatched setting can greatly increase eligible donor availability for BMT.

Since GVHD induction typically correlates with GVL responses, the mechanism or mechanisms by which $P \mathrm{KCO}^{-/-} \mathrm{T}$ cells specifically retain GVL activity are presently unclear. Nonetheless, nonmutually exclusive mechanisms that may contribute to this outcome include the following: (a) tumor cells are better targets for $T$ cells than epithelial cells (which are targeted in GVHD). In this context, we examined levels of MHC I and ICAM-1, a key adhesion/costimulatory molecule, on A20 versus epithelial cells (TUBO cell line) and fibroblasts from BALB/c mice. Interestingly, approximately 50 -fold greater expression of these molecules on A20 versus epithelial cells and fibroblasts was noticed (Supplemental Figure 7). Thus, lymphoid (e.g., A20) and potentially myeloid tumor cells may be better targets for alloreactive $\mathrm{T}$ cells than epithelial cells because of greater avidity $\mathrm{T}$ cell/target cell interaction. Furthermore, our results suggest that $P K C \theta^{-/-} \mathrm{T}$ cells respond better when challenged with higher affinity and/or higher avidity (i.e., higher alloantigen levels; Figure 5, C and D). (b) It has previously been shown that PKCO is required for FasL expression but not for exocytosis of perforin granules $(57,58)$, and the Fas/FasL pathway is more important for GVHD while the perforin pathway is more important for GVL responses by CTL $(59,60)$. Thus, $P K C \theta^{-/-} \mathrm{T}$ cells may be able to differentially induce GVL responses through selective retention of the perforin pathway. (c) PKC $\theta$ has been shown to be crucial in the TCR-mediated activation of $\beta 2$ integrin adhesion (61), and we recently provided evidence that $\beta 2$ integrin adhesion can separate GVHD and GVL by regulating $\mathrm{T}$ cell migration (28). Thus, $P \mathrm{KCO}^{-/-} \mathrm{T}$ cells may fail to infiltrate into GVHD target organs, yet adequate numbers of activated $\mathrm{PKCH}^{-/-} \mathrm{T}$ cells may be generated to eliminate tumor cells. Additional studies will be required to determine which specific mechanism or mechanisms are responsible for differences in GVHD versus GVL responses in the absence of PKC $\theta$.

In summary, our studies have provided what we believe are novel and fundamentally important insights into the biological function of PKC $\theta$. First, we show that PKC $\theta$ plays a key role in lowering the overall signaling threshold required for $\mathrm{T}$ cell activation. Thus, absence of PKC $\theta$ selectively impairs T cell activation by low-level and low-affinity TCR agonists. In the context of infection, the natural function of PKCO may therefore be to allow T cell activation by lower-affinity antigens and/or allow $\mathrm{T}$ cell activation under conditions of limited APC activation. Second, our findings identify PKC $\theta$ as a crucial regulator of $\mathrm{T}$ cell activation in allogeneic settings. Currently used immunosuppressive drugs broadly inhibit $\mathrm{T}$ cell activation by alloantigens as well as infectious agents, rendering recipients susceptible to life-threatening infections. In contrast, inhibition of PKC $\theta$ is expected to be uniquely efficacious in preventing GVHD while not having a significant impact on protective responses to infectious agents. In addition, deficiency of PKC $\theta$ in mice primarily has an impact on $\mathrm{T}$ cell responses (7), suggesting that targeting PKC $\theta$ will not result in widespread toxicity in nonlymphoid tissues. However, whether PKC $\theta$ targeting will also inhibit alloreactivity in the context of solid organ transplantation remains to be determined. Finally, we show that PKC $\theta$ is dispensable for GVL responses. Together, our findings validate PKC $\theta$ as a promising therapeutic target for preventing GVHD while preserving antiinfection and antitumor responses. PKC $\theta$ inhibitors may therefore broaden the use of allogeneic BMT in treatment of both malignant and nonmalignant disorders in the clinic. 


\section{Methods}

Mice and reagents. $\mathrm{PKC} \mathrm{K}^{-/-}$mice were provided by D.R. Littman (New York University, New York, New York, USA). Founders of 2C TCR Tg mice were provided by D. Loh (Nippon Roche Research Center, Kamakura, Japan). OT-1 and $2 \mathrm{C}$ mice were crossed to $\mathrm{PKC}^{-/-}$mice and bred to homozygosity. All colonies were maintained under specific pathogen-free conditions. All animal studies were approved by the Institutional Animal Care and Use Committees of the H. Lee Moffitt Cancer Center and the University of South Florida. CD8-FITC, CD45.2-APC, V 2 2-biotin, streptavidin-APC, CD44-FITC, IFN- $\gamma$-APC, IL-2-PE, and annexin V-PE fluorescent antibodies were purchased from BD Biosciences - Pharmingen or eBioscience. $\mathrm{K}^{\mathrm{b}}$ OVA tetramer-PE was obtained from Beckman Immunomics. Agonistic anti-CD3 and anti-CD28 Abs were obtained from eBioscience. The FGK45 agonistic anti-CD40 $\mathrm{Ab}$ has been previously described (62). OVA $257-264$ peptide (SIINFEKL; OVAp) and its low-affinity variant E1 (EIINFEKL) were purchased from Anaspec. The G4 peptide (SIIGFEKL) was provided by N. Gascoigne (Scripps Research Institute, La Jolla, California, USA). p2Ca (LSPFPFDL) and GL9 (QLSPFPFDL) peptides were purchased from United Biochemical Research. The TLR ligand LPS was purchased from SigmaAldrich. Cell cultures were done using RPMI 1640 medium supplemented with $10 \%$ FBS, $4 \mathrm{mM}$ L-glutamine, $0.1 \mathrm{mM}$ nonessential amino acids, $1 \mathrm{mM}$ sodium pyruvate, $100 \mathrm{U} / \mathrm{ml}$ penicillin and streptomycin, $10 \mathrm{mM}$ HEPES, and $5 \mu \mathrm{M}$ 2-ME (RP-10).

T cell purification. CD8 T cell purification from TCR Tg OT-1 and 2C mice was done using MACS magnetic cell sorting (Miltenyi Biotec). In brief, cells isolated from lymph nodes of naive animals were resuspended in $2 \%$ FBS medium and incubated for 20 minutes with biotin-labeled Abs specific for CD4, B220, I-Ab, and CD11c. Streptavidin-conjugated microbeads were added to the cells for an additional 30 minutes before passing them over LS separation columns attached to the MACS magnet. Tg cells were typically more than $93 \% \mathrm{CD}^{+}$and more than $95 \% \mathrm{CD}^{\mathrm{lo}}$. For experiments using non-Tg CD8 T cells, the Ab cocktail was supplemented with $0.5 \mu \mathrm{g}$ of biotinylated anti-CD44. Non-Tg cells were typically more than $98 \% \mathrm{CD}^{+}$and more than $99 \% \mathrm{CD}_{4} 4^{\mathrm{l}}$. Total $\left(\mathrm{CD}^{+}\right.$and $\left.\mathrm{CD} 8^{+}\right) \mathrm{T}$ cells were purified using the same protocol except for addition of biotin-labeled anti-CD4 mAbs.

Microsphere, BM-derived DCs, and whole-splenocyte preparation. For preparation of microspheres, $5-\mu \mathrm{m}$ sulfate latex microspheres (Invitrogen) were incubated with DimerX H-2 $\mathrm{K}^{\mathrm{b}}$ : Ig (BD Biosciences - Pharmingen) at $2.5 \mu \mathrm{g} / 10^{7}$ microspheres for 15 minutes at $4^{\circ} \mathrm{C}$ and pulsed with $0.1 \mu \mathrm{M} \mathrm{OVA}_{257-264}$ peptide (or as indicated) for 2 hours at $37^{\circ} \mathrm{C}$. When used, B7.1/Fc chimeric protein (R\&D Systems) was coimmobilized at $0.6 \mu \mathrm{g} / 10^{7}$ microspheres (or as indicated) for an additional 30 minutes at $4{ }^{\circ} \mathrm{C}$. Coated microspheres were washed extensively to remove free peptide. BMDCs were cultured from BM precursors. Cells were harvested, washed, and replated onto a 6 -cm dish at $1 \times 10^{6}$ cells $/ \mathrm{ml}$ for an additional day to induce maturation. DCs generated were more than $95 \%$ CD $11 c^{+}$. To obtain spleen APCs, spleens from syngeneic C57BL/6 or allogeneic Balb/c mice were perfused with $1 \mathrm{ml}$ collagenase $\mathrm{D}$ at $2 \mathrm{mg} / \mathrm{ml}$ in buffered solution (10 $\mathrm{mM}$ HEPES$\mathrm{NaOH}, \mathrm{pH}$ 7.4, $150 \mathrm{mM} \mathrm{NaCl}, 5 \mathrm{mM} \mathrm{KCl}, 1 \mathrm{mM} \mathrm{MgCl} 2,1.8 \mathrm{mM} \mathrm{CaCl}_{2}$ ). Perfused spleens were incubated in $5 \mathrm{ml}$ of collagenase buffer at $37^{\circ} \mathrm{C}$ for 30 minutes, homogenized to suspension, and washed, then resuspended in rbc lysis buffer for an additional 5 minutes. After 2 to 3 washing steps, splenocytes were resuspended in supplemented RPMI 1640 medium and irradiated with 20 Gy before mixing with T cells.

In vitro proliferation. For in vitro proliferation experiments, $1 \times 10^{5}$ purified naive CD8 T cells were mixed with $2 \times 10^{5}$ microspheres in flat-bottom plates or with $1 \times 10^{4} \mathrm{BMDCs}$ or 1 to $4 \times 10^{5}$ splenocytes in round-bottom plates in a total of $200 \mu \mathrm{l}$ supplemented RPMI 1640 media. ${ }^{3} \mathrm{H}$-thymidine was added in the final 10 hours of culture. All conditions were tested in triplicate, and the average and SD of incorporated radioactivity are shown.
Experiments that required the activation of non-Tg CD8 T cells by BMDCs were done by mixing $1 \times 10^{5}$ purified naive CD 8 T cells with $1 \times 10^{4}$ BMDCs in round-bottom plates that were precoated with anti-CD $3 \pm$ anti-CD28 agonistic antibodies at $1 \mu \mathrm{g} /$ well each.

Adoptive transfer and immunizations. To measure the in vivo response of OT-1 CD8 T cells to OVA immunizations, $2 \times 10^{6}$ purified naive CD8 T cells from $\mathrm{CD} 45.2^{+} \mathrm{OT}-1$ or OT-1/PKC ${ }^{-/-}$mice were transferred into age- and sexmatched congenic CD $45.1^{+} \mathrm{C} 57 \mathrm{BL} / 6$ recipients by i.v. (tail vein) injections. One day after cell transfer, recipient mice were immunized with whole OVA protein ( 10 or $100 \mu \mathrm{g} /$ mouse $)$ with or without LPS ( $25 \mu \mathrm{g} / \mathrm{mouse})$ in a total volume of $100 \mu \mathrm{l}$ by s.c. injection at the base of the tail. To measure the response of endogenous CD8 T cells to LM-OVA immunizations, the mice were immunized i.v. (tail vein) with $2 \times 10^{3} \mathrm{CFUs}$ of the bacterium.

In vivo proliferation and effector function. For in vivo proliferation of TCR Tg OVA-specific CD8 T cells, purified naive OT-1 or OT-1/PKC ${ }^{-/-} \mathrm{CD} 45.2^{+}$ CD8 T cells were labeled with $5 \mu \mathrm{M}$ CFDA-SE (CFSE; Invitrogen) and adoptively transferred into congenic CD $45.1^{+}$recipient mice. After immunization, draining inguinal lymph nodes were harvested and CFSE dilution was analyzed by FACS using antibodies to CD8 and CD45.2. In some experiments, the combined proliferation and survival (i.e., clonal expansion) of nonlabeled donor cells was counted as the total number of CD8 ${ }^{+} \mathrm{CD} 45.2^{+}$ donor $\mathrm{T}$ cells found in the draining lymph nodes of recipient mice. Clonal expansion of endogenous OVA-specific CD8 T cells after immunization with LM-OVA was detected by FACS using antibodies to CD8, CD44, and $\mathrm{K}^{\mathrm{b}} / \mathrm{OVA}$ tetramer. To measure the cytotoxic effector function of adoptively transferred OT-1 CD8 T cells after immunization, we used a previously described procedure (63). In brief, a suspension of syngeneic splenocytes obtained from $\mathrm{C} 57 \mathrm{BL} / 6$ mice was divided into 2 parts. One sample was pulsed with $0.1 \mu \mathrm{M} \mathrm{OVA}_{257-264}$ for 45 minutes at $37^{\circ} \mathrm{C}$, washed extensively, and incubated with a low concentration of CFSE $(0.5 \mu \mathrm{M})$. The other population was incubated without peptide, washed, and labeled with a high concentration of CFSE $(5 \mu \mathrm{M})$. Equal numbers of peptide-pulsed CFSE ${ }^{\text {lo }}$ cells and unpulsed CFSE $^{\text {hi }}$ cells were mixed, and a total of $2 \times 10^{7}$ CFSE-labeled splenocytes were transferred i.v. into recipient mice that had been previously injected with CD8 T cells and immunized as indicated. The fate of OVA peptide-pulsed versus unpulsed target cells was monitored 10-12 hours later in the spleen by FACS. The production of IFN- $\gamma$ by activated endogenous CD $8 \mathrm{~T}$ cells after LM-OVA immunizations was measured by intracellular staining.

Electrophoretic mobility shift assay and retroviral infection of CD8 T cells. Electrophoretic mobility shift assays (EMSAs) to detect nuclear localization of NF-KB were done as previously described (64). Retroviral infection of CD8 $\mathrm{T}$ cells with the constitutively active mutant IKK $\beta$ (EM), which contains both EE and M10 mutations, was done as previously described (25). In brief, purified OT-1 and OT-1/PKC ${ }^{-/-}$CD 8 T cells were mixed with $\mathrm{K}^{\mathrm{b}} / \mathrm{OVA}$-coated microspheres as described above. After 1 and 2 days of activation, cells were spin infected with retroviral supernatants at $1500 \mathrm{~g}$ for 1 hour at $30^{\circ} \mathrm{C}$ in the presence of $4 \mu \mathrm{g} / \mathrm{ml}$ polybrene (Sigma-Aldrich). Original culture supernatants were returned to the wells each time after infection, and the cells were allowed to remain in culture for an additional day. Because all retroviral constructs based on the MIG vector containing an internal ribosome entry site GFP cassette were used, infected cells were distinguished and sorted from uninfected cells by FACS at day 3. Sorted $\mathrm{GFP}^{+}$cells were mixed with newly made $\mathrm{K}^{\mathrm{b}} / \mathrm{OVA}$-coated microspheres and cultured for an additional 2 days. Proliferation levels from this secondary culture were measured by means of ${ }^{3} \mathrm{H}$-thymidine incorporation as described above.

MCMV infection. Mice were infected with $2 \times 10^{4}$ PFU MCMV by i.p. injection. 3 or 10 days later, mice were sacrificed and livers and spleens obtained to determine virus titer and MCMV-specific tetramer-positive CD8 T cells, respectively, as described previously $(44,45)$. 
GVHD and GVL. In nonmyeloablative models, bm1 mice at 7-8 weeks were exposed to $500 \mathrm{cGy}$ of total body irradiation from ${ }^{137} \mathrm{Cs}$ source at $120 \mathrm{cGy} / \mathrm{min}$. Freshly isolated $\mathrm{CD}^{+}$cells at indicated numbers were injected via the tail vein into bm1 recipients within 24 hours after irradiation. In myeloablative BMT models, BALB/c mice at 8- to 10-weeks old were exposed to $800-900 \mathrm{cGy}$ of total body irradiation from ${ }^{137} \mathrm{Cs}$ source at $120 \mathrm{cGy} / \mathrm{min}$. Sulfamethoxazole trimethoprim (Hi-Tech Pharmacal Inc.) was added to the drinking water of irradiated mice starting the day before irradiation and continuing throughout the entire experiment. TCD BM cells alone or in combination with purified T cells from indicated donors were injected via the tail vein to recipients within 24 hours after irradiation. Recipient mice were monitored every other day for clinical signs of GVHD, such as ruffled fur, hunched back, inactivity or diarrhea, and mortality. Animals judged to be moribund were sacrificed and counted as GVHD lethality. To establish a leukemia/lymphoma in the BMT recipients, 2000/mouse luciferase-expressing A20 cells (B cell lymphoma line derived from $B A L B / c$ mice) were given on the day of BMT. To distinguish mortality due to GVHD or tumor relapse, we used BLI technology to monitor tumor growth in vivo, which was established in our previous work (28). Recipient mice were monitored for body weight loss and clinical signs of GVHD 2-3 times a week, and monitored for tumor growth weekly by BLI. If recipient death was associated with weight loss and other signs of GVHD, with little or no BLI signal, we scored the death due to GVHD. If recipient death was associated with strong BLI signal, but few or no GVHD signs, we scored the death due to tumor relapse.

Statistics. The log-rank test was used to detect statistical differences in recipient survival in GVHD experiments. $P<0.05$ was defined as significant. Two- tailed Student's $t$ test was used to compare percentages or numbers of donor $\mathrm{T}$ cells, percentages of $\mathrm{T}$ cell apoptosis, tetramer ${ }^{+}$cells, and viral load.

\section{Acknowledgments}

We thank Claudio Anasetti, William Kerr, and Dmitry Gabrilovich (H. Lee Moffitt Cancer Center) for discussion; Sofia Hussain, Yaming Liang, Xingyu Wang, and Francisca Beato (H. Lee Moffitt Cancer Center) for technical assistance; Daniel R. Littman for providing $P \mathrm{KCO}^{-/-}$mice; and Nicholas Gascoigne for providing the G4 peptide. We also acknowledge help provided by Flow Cytometry and Molecular Biology core facilities at the H. Lee Moffitt Cancer Center. M. Prlic is a fellow of the Leukemia and Lymphoma Society. Work in B.R. Blazar's laboratory was supported by NIH grants R01 AI34495 and 2R01 HL56067. This work was supported by NIH grants R01 AI059715 and DOD BC011057 and by institutional funds from the H. Lee Moffitt Cancer Center (to A.A. Beg) and by NIH grant R01 CA118116 (to X.-Z. Yu).

Received for publication April 29, 2009, and accepted in revised form September 16, 2009.

Address correspondence to: Amer A. Beg or Xue-Zhong Yu, H. Lee Moffitt Cancer Center and Research Institute, 12902 Magnolia Drive, Tampa, Florida 33612, USA. Phone: (813) 745-5714; Fax: (813) 979-7265; E-mail: amer.beg@moffitt.org (A.A. Beg). Phone: (813) 745-3562; Fax: (813) 979-7265; E-mail: xue.yu@ moffitt.org (X.-Z. Yu).
1. Greenwald, R.J., Freeman, G.J., and Sharpe, A.H. 2005. The B7 family revisited. Annu. Rev. Immunol. 23:515-548.

2. Watts, T.H. 2005. TNF/TNFR family members in costimulation of $\mathrm{T}$ cell responses. Annu. Rev. Immunol. 23:23-68.

3. Curtsinger, J.M., Gerner, M.Y., Lins, D.C., and Mescher, M.F. 2007. Signal 3 availability limits the CD8 $\mathrm{T}$ cell response to a solid tumor. J. Immunol. 178:6752-6760.

4. Samelson, L.E. 2002. Signal transduction mediated by the $\mathrm{T}$ cell antigen receptor: the role of adapter proteins. Annu. Rev. Immunol. 20:371-394.

5. Spitaler, M., and Cantrell, D.A. 2004. Protein kinase $\mathrm{C}$ and beyond. Nat. Immunol. 5:785-790.

6. Isakov, N., and Altman, A. 2002. Protein kinase $\mathrm{C}$ (theta) in T cell activation. Annu. Rev. Immunol. 20:761-794.

7. Sun, Z., et al. 2000. PKC-theta is required for TCRinduced NF-kappaB activation in mature but not immature T lymphocytes. Nature. 404:402-407.

8. Pfeifhofer, C., et al. 2003. Protein kinase C theta affects $\mathrm{Ca} 2+$ mobilization and NFAT cell activation in primary mouse T cells. J. Exp. Med. 197:1525-1535.

9. Grumont, R., et al. 2004. The mitogen-induced increase in T cell size involves PKC and NFAT activation of Rel/NF-kappaB-dependent c-myc expression. Immunity. 21:19-30.

10. Barouch-Bentov, R., et al. 2005. Protein kinase $\mathrm{C}$-theta is an early survival factor required for differentiation of effector CD8+ T cells. J. Immunol. 175:5126-5134.

11. Berg-Brown, N.N., et al. 2004. PKCtheta signals activation versus tolerance in vivo. J. Exp. Med. 199:743-752.

12. Marsland, B.J., et al. 2007. TLR ligands act directly upon $T$ cells to restore proliferation in the absence of protein kinase C-theta signaling and promote autoimmune myocarditis. J. Immunol. 178:3466-3473.

13. Salek-Ardakani, S., So, T., Halteman, B.S., Altman, A., and Croft, M. 2005. Protein kinase Ctheta controls Th1 cells in experimental autoimmune encephalomyelitis. J. Immunol. 175:7635-7641.

14. Healy, A.M., et al. 2006. PKC-theta-deficient mice are protected from Th1-dependent antigeninduced arthritis. J. Immunol. 177:1886-1893.

15. Marsland, B.J., Soos, T.J., Spath, G., Littman, D.R., and Kopf, M. 2004. Protein kinase $C$ theta is critical for the development of in vivo $\mathrm{T}$ helper $(\mathrm{Th}) 2$ cell but not Th1 cell responses. J. Exp. Med. 200:181-189.

16. Marsland, B.J., et al. 2005. Innate signals compensate for the absence of PKC-\{theta\} during in vivo CD8(+) T cell effector and memory responses. Proc. Natl. Acad. Sci. U. S. A. 102:14374-14379.

17. Shlomchik, W.D. 2007. Graft-versus-host disease. Nat. Rev. Immunol. 7:340-352.

18. Ferrara, J.L., Levy, R., and Chao, N.J. 1999. Pathophysiologic mechanisms of acute graft-vs.-host disease. Biol. Blood Marrow Transplant. 5:347-356.

19. Welniak, L.A., Blazar, B.R., and Murphy, W.J. 2007. Immunobiology of allogeneic hematopoietic stem cell transplantation. Annu. Rev. Immunol. 25:139-170.

20. Marty, F.M., and Rubin, R.H. 2006. The persistent challenges of bacterial infections in the transplant recipient. Transpl. Infect. Dis. 8:125-127.

21. Rubin, R.H., and Marty, F.M. 2004. Principles of antimicrobial therapy in the transplant patient. Transpl. Infect. Dis. 6:97-100.

22. Reddy, P., et al. 2005. A crucial role for antigen-presenting cells and alloantigen expression in graft-versus-leukemia responses. Nat. Med. 11:1244-1249.

23. Harty, J.T., Schreiber, R.D., and Bevan, M.J. 1992. CD8 T cells can protect against an intracellular bacterium in an interferon gamma-independent fashion. Proc. Natl. Acad. Sci. U. S. A. 89:11612-11616.

24. Sakowicz-Burkiewicz, M., et al. 2008. Protein kinase $\mathrm{C}$-theta critically regulates the proliferation and survival of pathogen-specific $T$ cells in murine listeriosis. J. Immunol. 180:5601-5612.

25. Zheng, Y., Vig, M., Lyons, J., Van Parijs, L., and Beg, A.A. 2003. Combined deficiency of p50 and cRel in CD4+ T cells reveals an essential requirement for $\mathrm{NF}-\mathrm{kB}$ in regulating mature $\mathrm{T}$ cell survival and in vivo function. J. Exp. Med. 197:861-874.

26. Marsland, B.J., and Kopf, M. 2008. T-cell fate and function: PKC-theta and beyond. Trends Immunol. 29:179-185.

27. Yu, X.Z., et al. 2006. Opposing effects of ICOS on graft-versus-host disease mediated by CD4 and CD8 T cells. J. Immunol. 176:7394-7401.

28. Liang, Y., et al. 2007. \{beta\}2 integrins separates graft-versus-host disease and graft-versus-leukemia effect. Blood. 111:954-962.

29. Blazar, B.R., Korngold, R., and Vallera, D.A. 1997. Recent advances in graft-versus-host disease (GVHD) prevention. Immunol. Rev. 157:79-109.

30. Manicassamy, S., et al. 2008. A critical role for protein kinase $\mathrm{C}$-theta-mediated $\mathrm{T}$ cell survival in cardiac allograft rejection. J. Immunol. 181:513-520.

31. Yu, X.Z., Albert, M.H., and Anasetti, C. 2006. Alloantigen affinity and CD4 help determine severity of graft-versus-host disease mediated by CD8 donor T cells. J. Immunol. 176:3383-3390.

32. Yu, X.Z., Bidwell, S.J., Martin, P.J., and Anasetti, C. 2000. CD28-specific antibody prevents graft-versushost disease in mice. J. Immunol. 164:4564-4568.

33. Sha, W.C., et al. 1988. Positive and negative selection of an antigen receptor on $\mathrm{T}$ cells in transgenic mice. Nature. 336:73-76.

34. Sha, W.C., et al. 1988. Selective expression of an antigen receptor on CD8-bearing $\mathrm{T}$ lymphocytes in transgenic mice. Nature. 335:271-274.

35. Corr, M., et al. 1994. T cell receptor-MHC class I peptide interactions: affinity, kinetics, and specificity. Science. 265:946-949.

36. Cai, Z., and Sprent, J. 1996. Influence of antigen dose and costimulation on the primary response of CD8+ T cells in vitro. J. Exp. Med. 183:2247-2257.

37. Hogquist, K.A., et al. 1994. T cell receptor antagonist peptides induce positive selection. Cell. 76:17-27.

38. Yachi, P.P., Ampudia, J., Zal, T., and Gascoigne, N.R. 2006. Altered peptide ligands induce delayed CD8$\mathrm{T}$ cell receptor interaction - a role for CD8 in distinguishing antigen quality. Immunity. 25:203-211.

39. Yu, X.Z., Bidwell, S., Martin, P.J., and Anasetti, C. 
1999. Visualization, fate, and pathogenicity of antigen-specific CD8+ $\mathrm{T}$ cells in the graft-versus-host reaction. J. Immunol. 163:4780-4787.

40. Ahonen, C.L., et al. 2004. Combined TLR and CD40 triggering induces potent $\mathrm{CD} 8+\mathrm{T}$ cell expansion with variable dependence on type I IFN. J. Exp. Med. 199:775-784

41. Ahonen, C.L., et al. 2008. Enhanced efficacy and reduced toxicity of multifactorial adjuvants compared with unitary adjuvants as cancer vaccines. Blood. 111:3116-3125.

42. Assudani, D., Cho, H.I., DeVito, N., Bradley, N., and Celis, E. 2008. In vivo expansion, persistence, and function of peptide vaccine-induced CD8 T cells occur independently of CD4 T cells. Cancer Res. 68:9892-9899.

43. Taylor, P.A., et al. 2008. TLR agonists regulate alloresponses and uncover a critical role for donor APCs in allogeneic bone marrow rejection. Blood. 112:3508-3516.

44. Hossain, M.S., et al. 2007. Chronic GvHD decreases antiviral immune responses in allogeneic BMT. Blood. 109:4548-4556.

45. Hossain, M.S., Roback, J.D., Wang, F., and Waller, E.K. 2008. Host and donor immune responses contribute to antiviral effects of amotosalen-treated donor lymphocytes following early posttransplant cytomegalovirus infection. J. Immunol. 180:6892-6902.

46. Meyers, J.D., Flournoy, N., and Thomas, E.D. 1986. Risk factors for cytomegalovirus infection after human marrow transplantation. J. Infect. Dis. 153:478-488

47. Cohen, J.L., Trenado, A., Vasey, D., Klatzmann, D., and Salomon, B.L. 2002. CD4(+)CD25(+) immunoregulatory T Cells: new therapeutics for graft-ver- sus-host disease. J. Exp. Med. 196:401-406.

48. Gupta, S., et al. 2008. Differential requirement of PKC-theta in the development and function of natural regulatory T cells. Mol. Immunol. 46:213-224.

49. Waldman, E., et al. 2006. Absence of beta7 integrin results in less graft-versus-host disease because of decreased homing of alloreactive $\mathrm{T}$ cells to intestine. Blood. 107:1703-1711.

50. Petrovic, A., et al. 2004. LPAM (alpha 4 beta 7 integrin) is an important homing integrin on alloreactive $T$ cells in the development of intestinal graftversus-host disease. Blood. 103:1542-1547.

51. Choi, S.W., et al. 2007. CCR1/CCL5 (RANTES) receptor-ligand interactions modulate allogeneic T-cell responses and graft-versus-host disease following stem-cell transplantation. Blood. 110:3447-3455

52. Varona, R., Cadenas, V., Gomez, L., Martinez, A.C. and Marquez, G. 2005. CCR6 regulates CD4+ T-cell-mediated acute graft-versus-host disease responses. Blood. 106:18-26.

53. Terwey, T.H., et al. 2005. CCR2 is required for CD8-induced graft-versus-host disease. Blood. 106:3322-3330.

54. Wagner, J.E., et al. 2002. Transplantation of unrelated donor umbilical cord blood in 102 patients with malignant and nonmalignant diseases: influence of CD34 cell dose and HLA disparity on treatment-related mortality and survival. Blood. 100:1611-1618.

55. Barker, J.N., et al. 2005. Transplantation of 2 partially HLA-matched umbilical cord blood units to enhance engraftment in adults with hematologic malignancy. Blood. 105:1343-1347.

56. MacMillan, M.L., et al. 2009. Acute graft-versushost disease after unrelated donor umbilical cord blood transplantation: analysis of risk factors. Blood. 113:2410-2415.

57. Grybko, M.J., Pores-Fernando, A.T., Wurth, G.A., and Zweifach, A. 2007. Protein kinase $\mathrm{C}$ activity is required for cytotoxic $\mathrm{T}$ cell lytic granule exocytosis, but the theta isoform does not play a preferential role. J. Leukoc. Biol. 81:509-519.

58. Manicassamy, S., and Sun, Z. 2007. The critical role of protein kinase C-theta in Fas/Fas ligand-mediated apoptosis. J. Immunol. 178:312-319.

59. Schmaltz, C., et al. 2001. Differential use of Fas ligand and perforin cytotoxic pathways by donor $\mathrm{T}$ cells in graft-versus-host disease and graft-versusleukemia effect. Blood. 97:2886-2895.

60. Schmaltz, C. et al. 2002. T cells require TRAIL for optimal graft-versus-tumor activity. Nat. Med. 8:1433-1437.

61. Letschka, T., et al. 2008. PKC-theta selectively controls the adhesion-stimulating molecule Rap1. Blood. 112:4617-4627.

62. Fischbein, M.P., et al. 2000. CD40 signaling replaces CD4+ lymphocytes and its blocking prevents chronic rejection of heart transplants. J. Immunol. 165:7316-7322.

63. Mueller, S.N., Jones, C.M., Smith, C.M., Heath, W.R., and Carbone, F.R. 2002. Rapid cytotoxic $\mathrm{T}$ lymphocyte activation occurs in the draining lymph nodes after cutaneous herpes simplex virus infection as a result of early antigen presentation and not the presence of virus. J. Exp. Med. 195:651-656

64. Wang, X., et al. 2007. Lack of essential role of NF-kappa B p50, RelA, and cRel subunits in virus-induced type 1 IFN expression. J. Immunol. 178:6770-6776. 